ROYAL ONTARIO MUSEUM

LIFE SCIENCES

MISCELLANEOUS PUBLICATIONS

W. B. SCOT T

E. J.CROS S M A N

\title{
Checklist of Canadian
}

Freshwater Fishes with

Keys for Identification
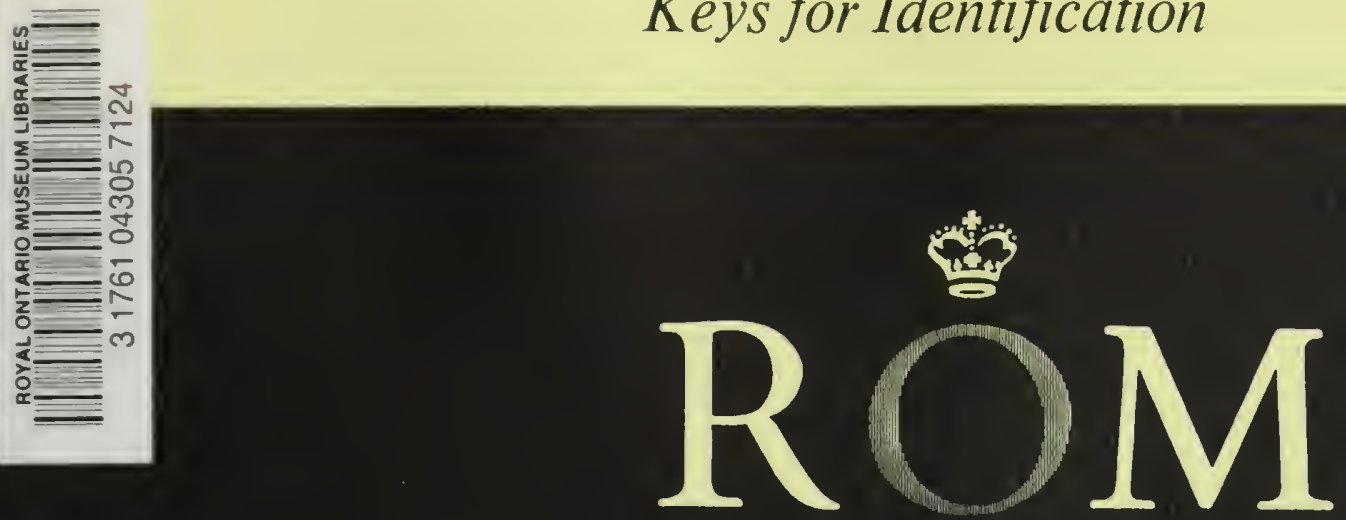

P.S.

Ro

690

536

1969 

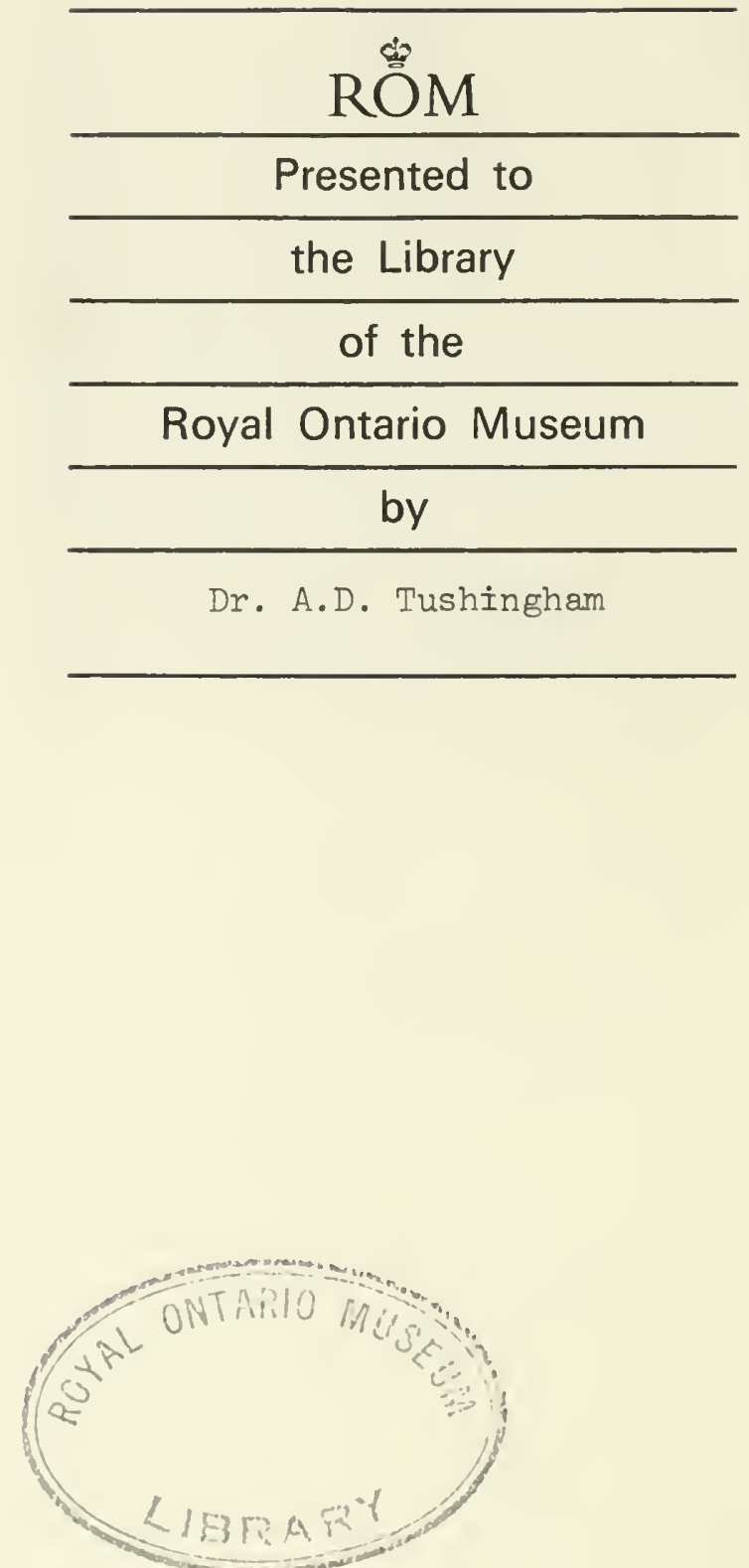


\section{CHECKLIST OF CANADIAN FRESHWATER FISHES}

WITH KEYS FOR IDENTIFICATION

W.B. SCOTT

and

E.J. CROSSMAN

\section{LIFE SCIENCES}

MISCELLANEOUS PUBLICATIONS

ROYAL ONTARIO MUSEUM

Publication date: September 1969

Suggested citation: Life Sci. Misc. Publ., R. Ont. Mus. 


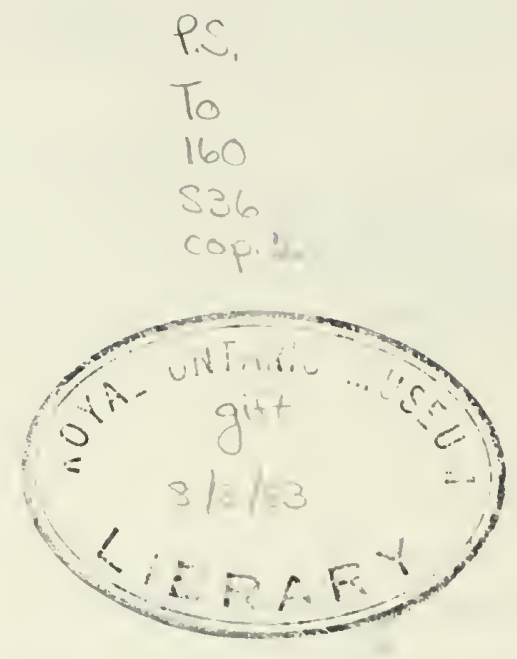


ROYAL ONTARIO MUSEUM

\section{PUBLICATIONS IN LIFE SCIENCES}

The Royal Ontario Museum publishes three series in the Life Sciences: LIFE SCIENCES CONTRIBUTIONS, a numbered series of original scientific publications, including monographic works.

LIFE SCIENCES OCCASIONAL PAPERS, a numbered series of original scientific publications, primarily short and usually of taxonomic significance.

LIFE SCIENCES MISCELLANEOUS PUBLICATIONS, an unnumbered series of publications of varied subject matter and format.

All manuscripts considered for publication are subject to the scrutiny and editorial policies of the Life Sciences Editorial Board, and to review by persons outside the Museum staff who are authorities in the particular field involved.

LIFE SCIENCES EDITORIAL BOARD, 1969

Chairman: P.C. SWANN

Director, Royal Ontario Musezon

Editors : G.B. WIGGINS

R.L. PETERSON

W.B. SCOTT is Curator (in charge) of the Department of Ichthyology and Herpetology, Royal Ontario Museum, and Professor in the Department of Zoology, University of Toronto.

E.J. CROSSMAN is Curator of the Department of Ichthyology and Herpetology, Royal Ontario Museum, and Associate Professor in the Department of Zoology, University of Toronto.

PRICE: $\$ 1.50$

(C) The Royal Ontario Museum, 1969

100 Queen's Park, Toronto, Canada 



\section{TABLE OF CONTENTS}

Introduction, 1

Acknowledgements, 3

Figures, 4

Checklist to Class, Order, Family and Species, 7

Map, following 25

Keys, 26

Species of Doubtful Occurrence, 75

Number of Species by Geographic Areas, 77

Number of Species in Major Watershed Basins, 77

Atlantic, 78

Huds on Bay, 80

Arctic, 82

Pacific, 83

Gulf of Mexico, 84

Literature Cited, 86

Index, 91 
Digitized by the Internet Archive in 2012 with funding from Royal Ontario Museum 


\section{INTRODUCTION}

This annotated checklist is an outgrowth of earlier lists released in 1958 and 1967. The keys are either newly prepared, adapting certain features of previously published keys, or are adapted from keys in other of the authors' publications (Scott and Crossman 1964; Leim and Scott 1966; Scott 1967). It is hoped that the present list and keys will serve as a useful aid to all those interested in the Canadian freshwater fish fauna. They also constitute a step in the preparation of a comprehensive text on the freshwater fishes of Canada, being sponsored by the Fisheries Research Board of Canada. The authors earnestly solicit constructive comments on the contents of this publication, so that the text mentioned may be as accurate as possible.

The checklist includes 183 species in 24 familles. Changes in nomenclature have occurred for many species since publication of previous lists. Such changes are designated in the present list by an annotation beginning with the word "Formerly ...". This list is in general accord, both in scientific and in common names, with Special Publication No. 2 (1960) of the American Fisheries Society entitled, "A list of common and scientific names of fishes from the United States and Canada", which is currently being revised.

For simplicity, we have avoided subspecies designations as separate entities, even when the two forms are known by distinct names. Annotated references are usually made to both forms when pertinent. For convenience, species are listed in alphabetical order within genera, subfamilies or families.

Below each species in the main body of the checklist is a series of annotations which designate the various political areas in which that species occurs. The meanings of the abbreviations are as follows:

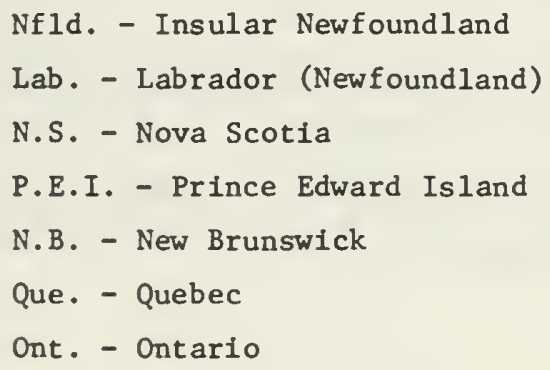

Man. - Manitoba

Sask. - Saskatchewan

Alta. - Alberta

B.C. - British Columbia

NWT. - Northwest Territories

Y.T. - Yukon Territory 
When species have been introduced, the province or territory is marked with an asterisk. If a question mark follows the asterisk, it indicates that the success of the introduction is in doubt.. For such species as the brown trout which are introduced throughout their Canadian range, the areas of occurrence are placed in parentheses and the asterisk appears only after the last parenthesis. For some native species such as the rainbow trout which are widely introduced outside their native range elsewhere in Canada, the areas of introduction are placed in parentheses and marked with an asterisk after the last parenthesis.

A section entitled, "Species of Doubtful Occurrence" has been included which lists fishes that have been recorded from fresh water, but whose occurrence is so rare or tenuous as to make their inclusion in the freshwater fauna questionable.

Also included are summaries of the number of species known to occur in the various provinces, territories, and major watersheds.

Our knowledge of Alberta fishes has been increased greatly, largely from a recent series of publications by Henderson and Peters (1969), Paetz (1967), Paetz and Nelson (1968), Willock (1968), and Willock (in press).

The artificial keys to the identity of the fishes consist of a key to the families and of keys to the species of each family represented by more than one species.

The keys are of the usual variety, consisting of couplets, each half of which leads to another couplet or to the name of a single species. We have attempted to avoid, wherever possible, the necessity of making a decision based on a single characteristic, or on only internal anatomical features. The keys are prepared for use in identifying both preserved and living fishes. Wherever prominent features of the living fish differ from those of the preserved specimen, or where features of living fish would assist in identification, they have been included.

The lamprey key is limited to adults, since the accurate identification of larval lampreys or ammocetes is unusually difficult and requires considerable care and experience.

In the family key, families represented by a single species in Canada do not have a page number leading to a key to the species. See the checklist entry for the family. 


\section{ACKNOWLEDGEMENTS}

The following people, who so kindly replied to our request for comments and suggestions contained in the 1967 list, have helped to make this list more accurate: Drs. K.R. Allen, R.M. Bailey, C.F. Cole, B.B. Collette, C.C. Lindsey, D.E. McAllister, J.S. Nelson, J.R. Nursall, and Messrs. R.E. Jenkins, J.J. Keleher, V. Legendre, C. Paterson, R.J. Paterson, T.A. Willock, D.E. Woroneck1.

The drawings were prepared by Mr. P. Buerschaper except the schematic drawing of the lamprey mouth which was made by Mr. A. Odum. The map was prepared by Miss Barbara Atkinson.

Misses Barbara Atkinson, Margaret Emery, Rebecca Rowlandson, Mrs. Milly Scott, Messrs. P. Buerschaper, S. Campbell and S. Taylor tested the various keys and assisted in the editing.

The demanding task of final editing and typing was cheerfully carried out by Monica Hunter.

We are grateful for the editorial advice and assistance given by Olive Koyama. 

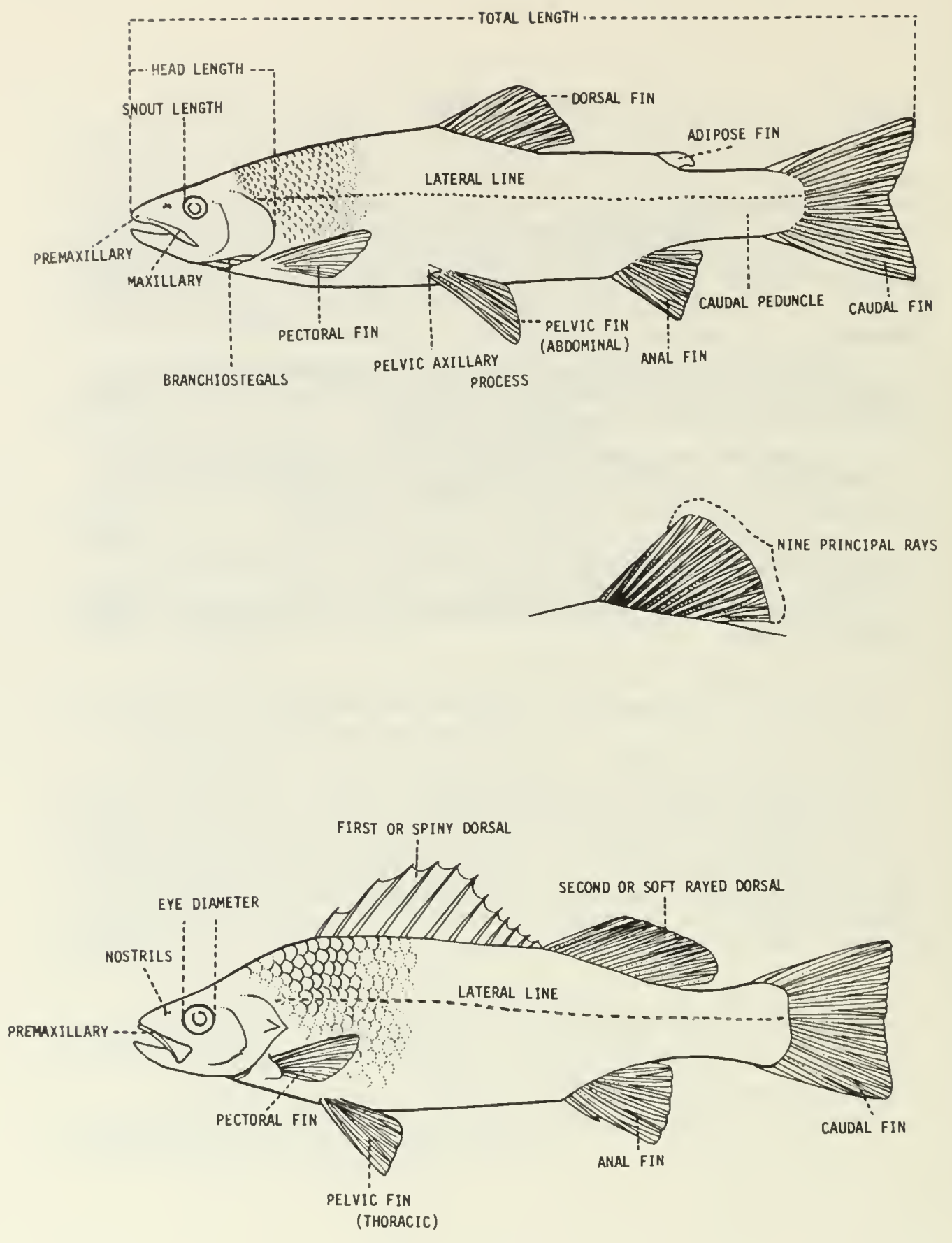

SKETCHES OF HYPOTHETICAL FISHES SHOWING FEATURES NOTED IN TEXT 

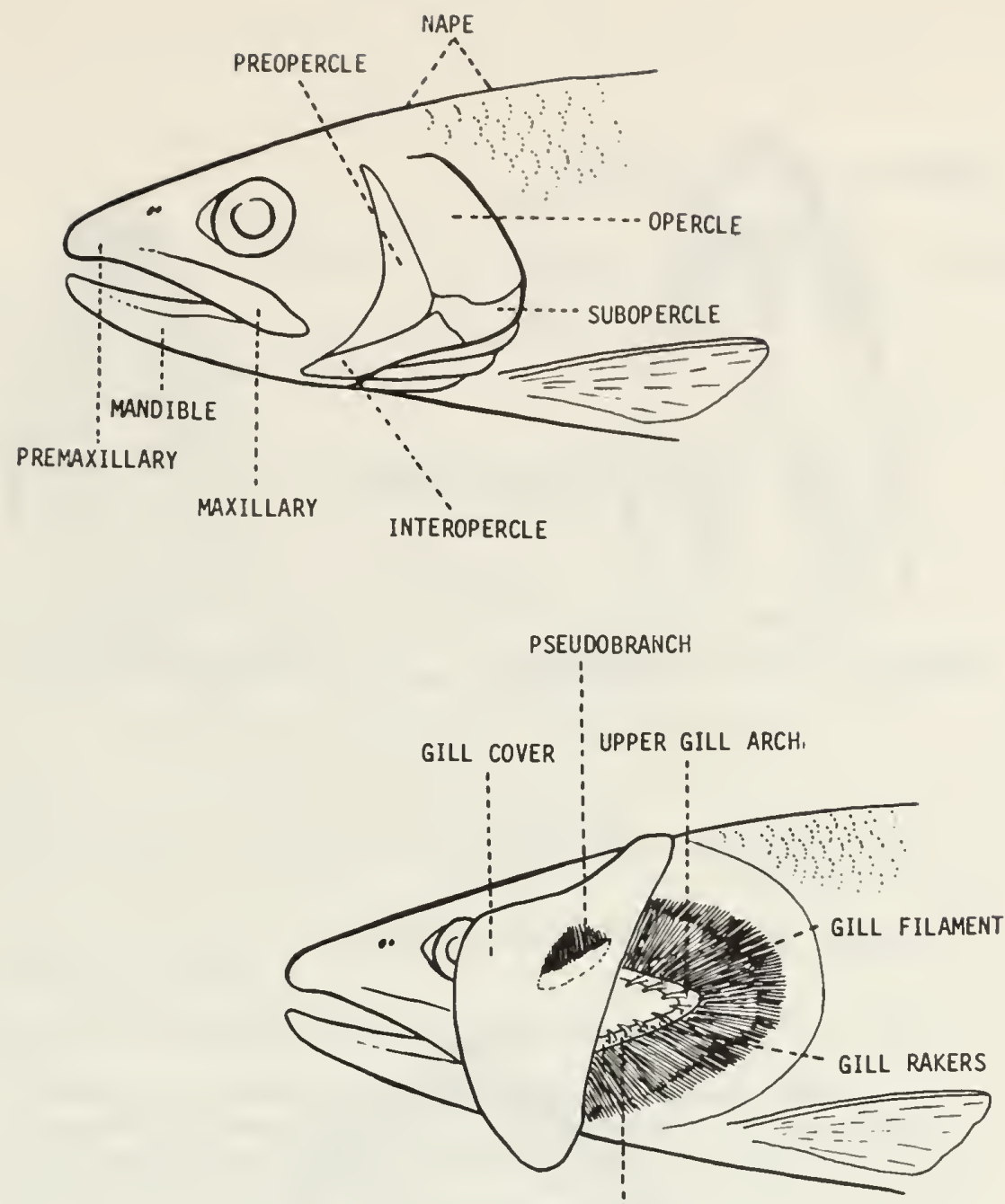

LOWER GILL ARCH

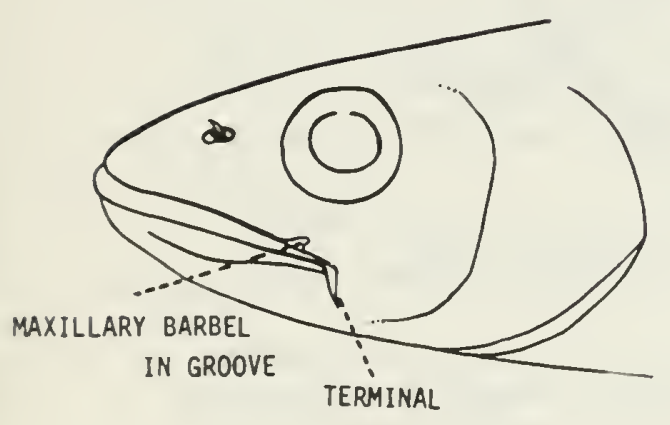

MAXILLARY BARBELS

SKETCHES OF HYPOTHETICAL FISHES SHOWING FEATURES NOTED IN TEXT 


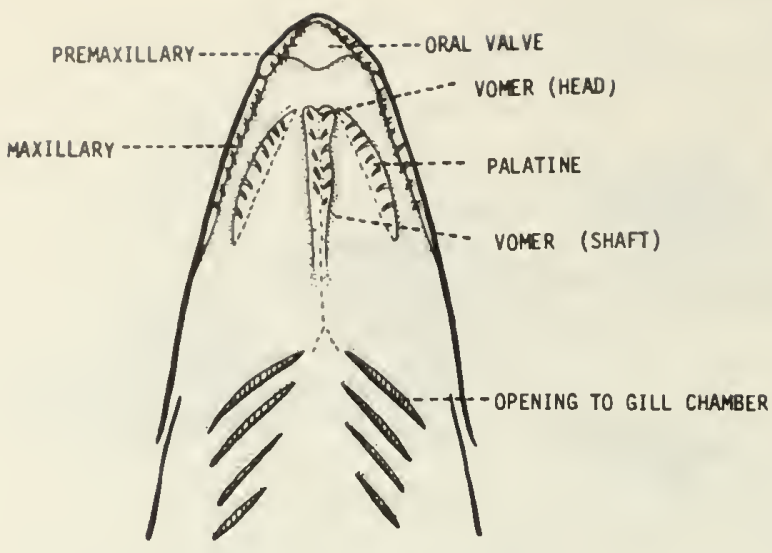

VENTRAL VIEW OF UPPER JAW, MOUTH AND PHARYNX

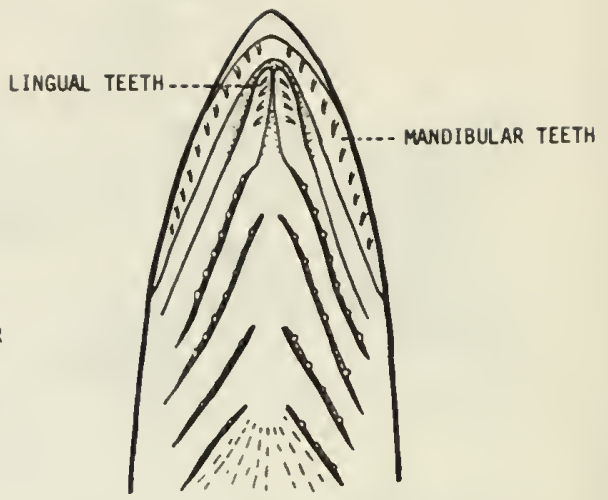

DORSAL VIEW OF LOWER JAW, MOUTH AND PHARYNX

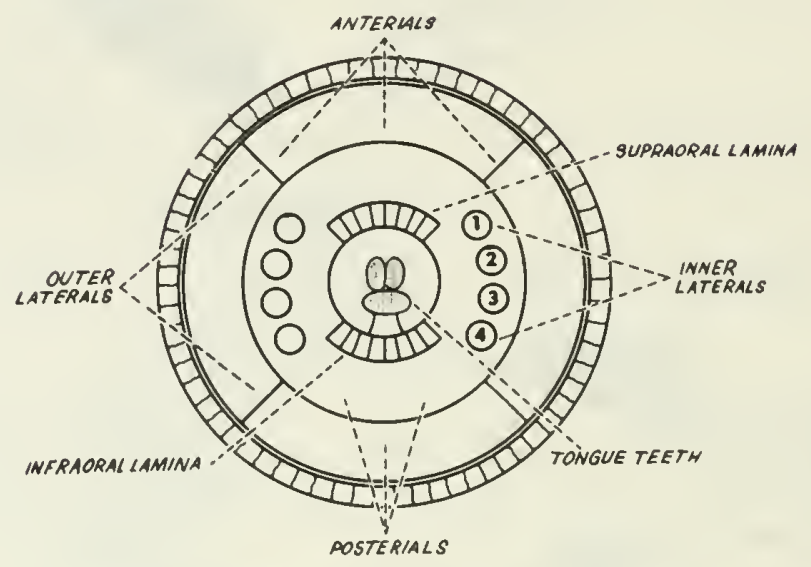

SCHEWTIC REPRESERTATION OF THE EUCCAL FUMUEL OF A LAPREY 
Class AGNATHA (Marsipobranchii)

Order PETROMYZONTIFORMES (Hyperoartia)

f. Petromyzontidae - lampreys

Entosphenus tridentatus (Gairdner) 1836 - Pacific lamprey

B.C., Alaska

Formerly Lampetra tri.dentata (Gairdner).

Ichthyomyzon castoneus Girard 1858 - chestnut lamprey Man.

Ichthyomyzon fossor Reighard and Cummins 1916 - northern bruok Que., Ont. lamprey

Ichthyomyzon rnicuspis Hubbs and Trautman 1937 - silver lamprey Que., Ont., Man.

Lampetra ayresi (Günther) 1870 - river lamprey

B.C.

Formerly L. fluviatilis (Linnaeus). L. ayresi previously relegated to synonymy of the European form $L$. fluviatilis. West Coast river lamprey shown by Vladykov and Follett, 1958, to be distinct.

Some species previously listed in the genus Entosphenus are now listed in the genus Lampetra.

Lampetra japonica (Martens) 1868 - Arctic lamprey

NWT., Y.T., Alaska

Formerly Entosphenus japonicus (Martens).

Lampetra Lomottei (Lesueur) 1827 - American brook lamprey Que., Ont.

Formerly Entosphenus Zamottei (Lesueur).

Lcompetra richardsoni Vladykov and Follett 1965 - western brook B.C.

lamprey

Formerly L. planeri (Bloch) which should be limited to the European brook lamprey from which the western brook lamprey is distinct (Vladykov and Follett, 1965). 
Petromyzon maxinus Linnaeus 1758 - sea lamprey

Nfld., N.S., P.E.I., N.B., Que., Ont.

\section{Class OSTEICHTHYES (Pisces)}

Order ACIPENSERIFORMES (Chondrostei)

f. Acipenseridae - sturgeons

Acipenser brevirostrom Lesueur 1818 - shortnose sturgeon

N.B.

Specimens have been taken in the St. John River (Scott and

Crossman, 1959; Magnin, 1963), and more by Gorham (pers. comm.).

Acipenser fulvescens Rafinesque 1817 - lake sturgeon

Que., Ont., Man., Sask., Alta.

Acipenser medirostris Ayres 1854 - green sturgeon

B.C., Alaska

Acipenser oxyrhynchus Mitchill 1815 - Atlantic sturgeon

Nfld., Lab., N.S., P.E.I., N.B., Que.

Magnin and Beaulieu (1963) and Magnin (1964) concluded that

this species was distinct from $A$. stumio.

Acipenser transmontanus Richardson 1836 - white sturgeon

B.C., Alaska

Order LEPISOSTEIFORMES (Semionotiformes, Protospondyli,

Ginglymodi)

f. Lepisosteidae - gars

Lepisosteus oculatus (Winchell) 1864 - spotted gar

Ont.

Formerly L. productus (Cope) 1865.

Lepisosteus osseus (Linnaeus) 1758 - longnose gar

Que., Ont. 
Order AMIIFORMES (Halecomorphi)

f. Amildae - bowfin

Amia calva Linnaeus 1766 - bowfin

Que., Ont.

Order CLUPEIFORMES (Isospondyli)

f. Clupeidae - herrings

Alosa aestivalis (Mitchill) 1815 - blueback herring

N.B.

Alosa pseudoharengus (Wilson) 1811 - alewife

Nfld., Lab., N.S., P.E.I., N.B., Que., Ont.

Alosa sapidissima (Wilson) 1811 - American shad

Nfld., N.S., P.E.I., N.B., Que., Ont., B.C.*, Alaska*

Dorosoma cepedianum (Lesueur) 1818 - gizzard shad

Que., Ont.

f. Salmonidae - salmons, trouts, whitefishes, and grayling

A previous 1ist (Scott, 1958) used the family names

Salmonidae, Coregonidae, and Thymallidae, but we have included the latter two under the one family, Salmonidae.

For convenience, however, we are employing the widely recognized subfamily designations Salmoninae, Coregoninae, and Thymallinae. The genus Leucichthys becomes a subgenus of Coregonus in agreement with present usage. The genus Prosopium previously combined with Coregonus by some authors, (Eschmeyer and Bailey, 1955; Wilimovsky, 1954; Legendre, 1954) but retained in Scott 1958, was later reinstated (Norden, 1961).

subf. Salmoninae

Oncorhynchus gorbuscha (Walbaum) 1792 - pink salmon

Nfld.*?, Ont.*?, B.C., NWT., Y.T., Alaska 
Oncorhynchus keta (Walbaum) 1792 - chum salmon Ont.*?, B.C., NWT., Y.T., Alaska

Oncorhynchus kisutch (Walbaum) 1792 - coho salmon

Ont.*?, B.C., Y.T., Alaska

Ontario was included in previous lists on the basis of liberations in Lake Erie in 1933. It is included in this list on the basis of recent introductions into Ontario waters.

Oncorhynchus nerka (Walbaum) 1792 - sockeye salmon; kokanee Ont.*, Alta.*?, B.C., Y.T., Alaska

Ontario is included on the basis of 1966 spawning runs of kokanee in streams tributary to Georgian Bay and Lake Huron, resulting from liberations in Ontario in 1964 and 1965. It was recently introduced into Alberta.

Oncorhynchus tshowytscha (Walbaum) 1792 - chinook salmon Ont.*?, B.C., Y.T., Alaska

Salmo clarki Richardson 1836 - cutthroat trout; coastal cutthroat; Yellowstone cutthroat

Que.*, Alta., B.C., Alaska

The coastal cut throat trout, S. c. clarki Richardson 1836, and the Yellowstone cutthroat trout, $S$. c. Zewisi (Girard) 1856 are considered here as components of the same species following the AFS list. See Qadri (1959) for a statement of distinctions.

Salmo gaironeri Richardson 1836 - steelhead trout; rainbow trout; Kamloops trout

(Nfld., N.S., P.E.I., N.B., Que., Ont., Man., Sask.)*, Alta., B.C., Y.T., Alaska

Salmo salar Linnaeus 1758 - Atlantic salmon; lake Atlantic salmon; ouananiche

Nfld., Lab., N.S., P.E.I., N.B., Que., Ont.*

Although originally native to Lake Ontario, current Ontario stocks result from introductions.

Salmo trutta Linnaeus 1758 - brown trout

(Nfld., N.S., N.B., Que., Ont., Man., Sask., Alta., B.C.)*

Salvelinus alpinus (Linnaeus) 1758 - Arctic char

Nfld., Lab., N.B., Que., Ont., Man., NWT., Y.T., Alaska

Clarification of the distinction of $S$. alpinus and $S$. malma is given in McPhail (1961) who also placed $S$. marstoni, the Quebec red trout, $S$. oquossa and $S$. aureolus within the synonymy of $S$. alpinus. 
Salvelinus fontinalis (Mitchill) 1814 - brook trout

Nf1d., Lab., N.S., P.E.I., N.B., Que., Ont., Man., Sask.*, Alta.*, B.C.*, Alaska*

The aurora trout, Salvelinus timagamiensis Henn and

Rinkenbach 1925 , is here considered conspecific with

S. fontinalis (see Sale, 1967).

The splake or wendigo is an artificial hybrid form

for which Salvelinus fontinalis is the male parent.

See lake trout.

Salvelinus malma (Walbaum) 1792 - Dolly Varden

Alta., B.C., NWT., Y.T., Alaska

See S. alpinus and McPhail, 1961.

Salvelinus nomaycush (Walbaum) 1792 - lake trout

Lab., N.S., N.B., Que., Ont., Man., Sask., Alta., B.C.,

NWT., Y.T., Alaska

Although a hybrid rather than a distinct species, the splake or wendigo is now an important fish. It is the result of hybridizing male Salvelinus fontinalis and female Salvelinus nomaycush.

subf . Coregoninae

Coregonus alpenae (Koelz) 1924 - longjaw cisco Ont.

Coregonus artedii Lesueur 1818 - cisco; lake herring (tullibee in western Canada)

Que., Ont., Man., Sask., Alta., NWT.

Western Canada populations are perhaps best regarded as

"C. artedii complex" (McPhail and Lindsey, pers. comm.).

Coregonus autumnalis (Pallas) 1776 - Arctic cisco

NWT., Y.T., Alaska

Previously called lauretta herring. See McPhail (1966) for discussion of $C$. loourettae and $C$. autumalis.

Coregonus clupeaformis (Mitchil1) 1818 - lake whitefish

Nfld.*, Lab., N.B., Que., Ont., Man., Sask., Alta., B.C., NWT., Y.T., Alaska

Following the suggestion of Lindsey (pers. comm.) we treat here a possible complex of three forms: the broadly distributed lake whitefish, C. clupeaformis; the humpback whitefish, C. pidschian Gmelin 1788 of Alaska coastal waters and $C$. nelsoni Bean 1884. Lindsey (1963) validated C. nelsoni as a separate species occurring in the NWT. and Y.T. and later suggested the common name Yukon whitefish. 
Coregonus hoyi (Gill) 1872 - bloater

Ont.

Coregonus johannae (Wagner) 1910 - deepwater cisco

Ont.

Coregonus kiyi (Koelz) 1921 - kiyi

Ont.

Coregonus laurettae Bean 1882 - Bering cisco

Alaska

See McPhail (1966) for discussion of this and C. autromalis complex. Our 1967 list used lauretta as the common name.

McPhail and Lindsey (in press) propose the name Bering cisco.

Coregonus nasus (Pallas) 1776 - broad whitefish

B.C., NWT., Y.T., Alaska

See Lindsey (1962) for comments concerning taxonomy of this and other northwestern whitefishes.

Coregonus nigripinnis (Gill) 1872 - blackfin cisco

Ont., Man., Sask., Alta.

Coregonus nipigon (Koelz) 1925 - Nipigon cisco

Que., Ont., Man.

Coregonus reighardi (Koelz) 1924 - shortnose cisco

Ont.

Coregonus sardinella Valenciennes 1848 - least cisco

B.C., NWT., Y.T., Alaska

Coregonus zenithicus (Jordan and Evermann) 1909 - shortjaw cisco Ont., Man., Sask., Alta., NWT.

Coregonus sp.

N.S.

New species, restricted to N.S. waters.

Prosopizon coulteri (Eigenmann and Eigenmann) 1892 - pygmy whitefish Ont., B.C., Y.T., Alaska

Prosopizon cylindracerm (Pallas) 1784 - round whitefish

Lab., N.B., Que., Ont., Man., Sask., B.C., NWT., Y.T., Alaska 
Prosopizon williomsoni (Girard) 1856 - mountain whitefish

Alta., B.C., Y.T.

$P$. oregonizm is here considered to be a synonym of $P$.

williamsoni. See Holt (1960) for a comparative study.

Stenodus Zeucichthys (Güldenstadt) 1772 - inconnu

B.C., NWT., Y.T., Alaska

subf. Thymallinae

Thymallus arcticus (Pallas) 1776 - Arctic grayling

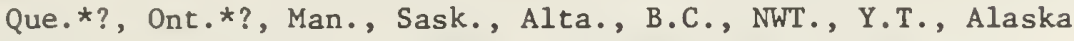

f. Osmeridae - smelts

Hypomesus olidus (Pallas) 1814 - pond smelt

NWT., Y.T., Alaska

Osmerus eperlanus Linnaeus 1758 - rainbow smelt

Nfld., Lab., N.S., P.E.I., N.B., Que., Ont., B.C., NWT., Y.T., Alaska

This form constitutes a perlexing complex in North America. In 1967 we listed 0 . eperlanus Linnaeus, rainbow smelt for the western and arctic populations and 0 . mordax (Mitchili), American smelt,for the eastern populations. The arctic population had been referred to previously as 0 . dentex Steindachner, and as $0 . e$. dentex by Wynne-Edwards (1952) and Walters (1955). McAllister (1963) synonymized 0 . dentex with 0 . mordax. We recognize here, the great difficulty of artificially separating individuals from the arctic and eastern populations and call them one species. However, as a result of the overwhelming geographic separation it would seem useful to retain the subspecific designations $0 . e$. dentex, Arctic smelt and

0 . e. mordax, American smelt.

Spirinchus thaleichthys (Ayres) 1860 - longfin smelt B.C.

McAllister (1963) referred the longfin smelt, Spirinchus dilatus Schultz and Chapman 1934, to the synonymy of the Sacramento smelt, Spirinchus thaleichthys and recommended the common name, longfin smelt.

Thaleichthys pacificus (Richardson) 1836 - eulachon B.C., Alaska 
f. Hiodontidae - mooneyes

Hiodon alosoides (Rafinesque) 1819 - goldeye

Que., Ont., Man., Sask., Alta., B.C., NWT.

Hiodon tergisus Lesueur 1818 - mooneye

Que., Ont., Man., Sask.

f. Umbridae - mudminnows

Dallia pectoralis Bean 1880 - Alaska blackfish

Ont.*?, Alaska

The genus Dallia previously listed in the family Dalliidae is currently considered to be insufficiently distinct from the genus Umbra to warrant family designation.

Umbra limi (Kirtland) 1840 - central mudminnow

Que., Ont., Man., Sask.

f. Esocidae - pikes

Esox coneriçanus Gmelin 1788 - redfin and grass pickerels

Que., Ont.

The redfin and grass pickerels, previously listed as separate species, were considered by Crossman (1966) to be only subspecifically distinct, i.e. E. a. comericanus Gmelin, the redfin pickerel and $E$. a. vermiculatus Lesueur 1846 , the grass pickerel.

Esox Zucius Linnaeus 1758 - northern pike

Lab., Que., Ont., Man., Sask., Alta., B.C., NWT., Y.T., Alaska

Esox masquinongy Mitchill 1824 - muskellunge

Que., Ont., Man.

Esox niger Lesueur 1818 - chain pickerel N.S.*, N.B., Que.

Order CYPRINIFORMES (Ostariophysi)

f. Cyprinidae - minnows

Acrocheilus alutaceus Agassiz and Pickering 1855 - chiselmouth B.C.

Previously spelled $A$. alutaceron. 
Carassius auratus (Linnaeus) 1758 - goldfish

(Ont., Alta., B.C.)*

Chrosomus eos Cope 1862 - northern redbelly dace

N.S., P.E.I., N.B., Que., Ont., Man., Sask., Alta., B.C.

Chrosomus neogaeus (Cope) 1866 - finescale dace

N.B., Que., Ont., Man., Sask., Alta., B.C., NWT.

Formerly Pfrizle neogaea (Cope). Many authors following

Bailey (1951) have enlarged the genus Chrosomus to include

this species.

Clinostomus elongatus (Kirtland) 1836 - redside dace

Ont.

Couesius plrombeus (Agassiz) 1850 - lake chub

Lab., N.S., N.B., Que., Ont., Man., Sask., Alta., B.C., NWT., Y.T., Alaska

Many authors following Bailey (1951) have enlarged the genus Hybopsis to include the genera Couesius, Nocomis, Erimystax and Platygobio. However, we prefer to retain Couesius, Nocomis and Platygobio.

Cyprinus carpio Linnaeus 1758 - carp

(Que., Ont., Man., Sask., B.C.)*

Exoglossum maxillingua (Lesueur) 1817 - cutlips minnow

Que., Ont.

Hybognathus hankinsoni Hubbs 1929 - brassy minnow

Que., Ont., Man., Sask., Alta., B.C.

Hybognathus nuchalis Agassiz 1855 - silvery minnow Que., Ont., Alta.

Hybopsis storeriana (Kirtland) 1842 - silver chub Ont., Man.

Hybopsis $x$-punctata Hubbs and Crowe 1956 - gravel chub Ont.

Formerly Emimystax dissimilis (Kirtland) 1841; see Couesius plrombeus above concerning genus. Hubbs and Crowe (1956) established this new name for the gravel chub.

Mylocheilus caurinus (Richardson) 1836 - peamouth

Alta., B.C.

Previously spelled M. cauminum. 
Nocomis biguttatus (Kirtland) 1840 - hornyhead chub Que., Ont., Man.

Formerly Hybopsis biguttata (Kirtland); see Couesius plumbeus above.

Nocomis micropogon (Cope) 1864 - river chub Cnt.

Formerly Hybopsis micropogon (Cope); see Couesius plumbeus above.

Notemigonus crysoleucas (Mitchil1) 1814 - golden shiner

N.S., P.E.I.*, N.B., Que., Ont., Man., Sask.

Notropis anogenus Forbes 1885 - pugnose shiner

Ont.

Notropis atherinoides Rafinesque 1818 - emerald shiner

Que., Ont., Man., Sask., Alta., B.C., NWT.

Notropis bifrenatus (Cope) 1867 - bridle shiner

Que., Ont.

Notropis blennius (Girard) 1856 - river shiner

Man., Sask., Alta.

Notropis chrysocephalus (Rafinesque) 1820 - striped shiner

Ont.

Recently considered a subspecies of $N$. comutus but re-erected to species by Gilbert (1964) who called it striped shiner. It is not included in the 1960 AFS list. Cross (1967) listed it but called it central common shiner.

Notropis cormutus (Mitchill) 1817 - common shiner

N.S., N.B., Que., Ont., Man., Sask.

Notropis heterodon (Cope) 1864 - blackchin shiner

Que., Ont.

Notropis heterolepis Eigenmann and Eigenmann 1893 - blacknose shiner N.S., N.B., Que., Ont., Man., Sask.

Notropis hudsonius (Clinton) 1824 - spottail shiner

Que., Ont., Man., Sask., Alta., NWT. 
Notropis mbellus (Agassiz) 1850 - rosyface shiner Que., Ont., Man.

Notropis spiloptemus (Cope) 1866 - spotfin shiner Que., Ont.

Notropis stromineus (Cope) 1864 - sand shiner Que., Ont., Man., Sask.

Formerly Notropis deliciosus (Girard) 1856. The specimens on which Notropis deliciosus was based were in effect N. texanus (Girard). The next available name for the species is stramineus (Suttkus, 1958).

Notropis umbratilis (Girard) 1856 - redfin shiner Ont.

Notropis volucellus (Cope) 1864 - mimic shiner Que., Ont., Man.

Opsopoeodus emiliae Hay 1880 - pugnose minnow Ont.

Pimephales notatus (Rafinesque) 1820 - bluntnose minnow Que., Ont., Man.

Pimephales promelas Rafinesque 1820 - fathead minnow N.B., Que., Ont., Man., Sask., Alta., NWT.

Platygobio gracilis (Richardson) 1836 - flathead chub Man., Sask., Alta., B.C., NWT., Y.T.

Ptychocheilus oregonensis (Richardson) 1836 - northern squawfish B.C., Alta.

Previously spelled $P$. oregonense.

Rhinichthys atratulus (Hermann) 1804 - blacknose dace N.S., N.B., Que., Ont., Man.

Rhinichthys cataractae (Valenciennes) 1842 - longnose dace Lab., Que., Ont., Man., Sask., Alta., B.C., NWT., Y.T.

Rhinichthys falcatus (Eigenmann and Eigenmann) 1893 - leopard dace B.C.

Rhinichthys osculus (Girard) 1856 - speckled dace B.C. 
Richardsonius balteatus (Richardson) 1836 - redside shiner Alta., B.C.

Semotilus atromaculatus (Mitchill) 1818 - creek chub

N.S., N.B., Que., Ont., Man.

Semotilus corporalis (Mitchill) 1817 - fallfish

N.B., Que., Ont.

Semotilus margarita (Cope) 1866 - pearl dace

N.S., N.B., Que., Ont., Man., Sask., Alta., B.C., NWT., Y.T. Formerly Margariscus margarita nachtriebei (Cox) 1894.

Tinca tinca (Linnaeus) 1758 - tench

B. C. *

\section{f. Catostomidae - suckers}

Carpiodes cyprinus (Lesueur) 1817 - quillback

Que., Ont., Man., Sask., Alta.

Catostomus catostomus (Forster) 1773 - longnose sucker

Lab., N.B., Que., Ont., Man., Sask., Alta., B.C., NWT., Y.T., Alaska

Catostomus colrombianus (Eigenmann and Eigenmann) 1893 - bridgelip B.C. sucker

Catostomus commersoni (Lacépède) 1803 - white sucker Lab., N.S., N.B., Que., Ont., Man., Sask., Alta., B.C., NWT.

Catostomus macrocheilus Girard 1856 - largescale sucker Alta., B.C.

Catostomus platyrhynchus (Cope) 1874 - mountain sucker Sask., Alta., B.C.

Formerly Pantosteus jordani Evermann, 1893. Smith (1966) considered Pantosteus characteristics to be only of subgeneric rank within the genus Catostomus. He synonymized P. platyrhynchus Cope 1874, P. jordani Evermann 1893 and P. Zahontan Rutter 1903 under the oldest specific name. The adjective, northern, is no longer appropriate.

Erimyzon sucetta (Lacépède) 1803 - lake chubsucker Ont. 
Hypentelion nigricans (Lesueur) 1817 - northern hogsucker ont.

Ictiobus cypminellus (Valenciennes) 1844 - bigmouth buffalo Ont., Man., Sask.

Formerly Megastomatobus cypminella. Note that Ictiobus bubalus (Rafinesque) 1819, the smallmouth buffalo, is omitted. Scott (1958) noted that Halkett's (1913) checklist was the only basis for subsequent listings and that no valid Canadian record exists.

Minytrema melanops (Rafinesque) 1820 - spotted sucker Ont.

Long known in U.S. tributaries of the Great Lakes, this species was first taken from Canadian waters of Lake St. Clair in 1962 (Crossman and Ferguson, 1963).

Moxostoma anisumom (Rafinesque) 1820 - silver redhorse Que., Ont., Man., Sask., Alta.

Moxostoma carinatum (Cope) 1870 - river redhorse Que., Ont.

Moxostoma duquesnei (Lesueur) 1817 - black redhorse Ont.

Moxostoma erythrumom (Rafinesque) 1818 - golden redhorse Ont.

Moxostoma hubbsi Legendre 1942 - copper redhorse Que.

Moxostoma macrolepidotion (Lesueur) 1817 - northern redhorse Que., Ont., Man., Sask., Alta.

Formerly Moxostoma aureolzon (Lesueur).

Moxostoma valenciennesi Jordan 1885 - greater redhorse Que., Ont.

$$
\text { f. Ictaluridae - catfishes }
$$

Ictalums melas (Rafinesque) 1820 - black bullhead Ont., Man., Sask., B.C.*

Ictalums natalis (Lesueur) 1819 - yellow bullhead Ont. 
Ictalurus nebulosus (Lesueur) 1819 - brown bullhead

N.S., N.B., Que., Ont., Man., Sask., B.C.*

Ictalurus punctatus (Rafinesque) 1818 - channel catfish

Que., Ont., Man.

Notums flavus Rafinesque 1818 - stonecat

Que., Ont., Alta.

Notumus gyminus (Mitchil1) 1818 - tadpole madtom

Que., Ont., Man., Sask.

Formerly Schilbeodes gyrinus (Mitchill).

Noturns miurus Jordan 1877 - brindled madtom

Ont.

Formerly Schilbeodes miumus (Jordan).

Order ANGUILLIFORMES (Apodes)

f. Anguillidae - freshwater eels

Anguizla rostrata (Lesueur) 1817 - American eel

Nfld., Lab., N.S., P.E.I., N.B., Que., Ont.

Order CYPRINODONTIFORMES (Mycrocyprini)

f. Cyprinodontidae - killifishes

Fundulus diaphanus (Lesueur) 1817 - banded killifish

Nfld., N.S., P.E.I., N.B., Que., Ont., Man.

Fundulus heteroclitus (Linnaeus) 1766 - mummichog

Nfld., N.S., P.E.I., N.B., Que.

Gombusia affinis (Baird and Girard) 1853 - mosquitofish

Alta.

Paetz and Nelson (1968) stated that this species was introduced into the outflow of Cave and Basin Hotsprings in 1924 for mosquito control and that the population still exists. 
f. Gadidae - cods

Lota Zota (Linnaeus) 1758 - burbot

Lab., N.B., Que., Ont., Man., Sask., Alta., B.C., NWT., Y.T., Alaska

Microgadus tomcod (Walbaum) 1792 - Atlantic tomcod

Nfld., Lab., N.S., P.E.I., N.B., Que.

Order ATHERINIFORMES

f. Atherinidae - silversides

Labidesthes sicculus (Cope) 1865 - brook silverside Que., Ont.

Order GASTEROSTEIFORMES (Thoracostei)

f. Gasterosteidae - sticklebacks

Apeltes quadracus (Mitchill) 1815 - fourspine stickleback

Nfld., N.S., P.E.I., N.B., Que.

Culaea inconstans (Kirtland) 1841 - brook stickleback

N.B., Que., Ont., Man., Sask., Alta., B.C., NWT.

Formerly Eucalia inconstans. The generic name Eucalia was pre-occupied and the new generic name was proposed by Whitley (1950).

Gasterosteus aculeatus Linnaeus 1758 - threespine stickleback

Nfld., Lab., N.S., P.E.I., N.B., Que., Ont., B.C., NWT., Alaska

Gasterosteus wheatlandi Putnam 1867 - blackspot stickleback

Nfld., N.B., Que.

This species, not previously listed and of ten confused with

G. aculeatus, was reported from Quebec by McAllister (1960)

and from Newfoundland by Scott and Crossman (1964). The name

blackspot stickleback is preferred, since twospine is inaccurate. 
Prongitius prongitius (Linnaeus) 1758 - ninespine stickleback Nfld., Lab., N.S., P.E.I., N.B., Que., Ont., Man., Sask., Alta., B.C., NWT., Y.T., Alaska

\section{Order PERCOPSIFORMES (Salmopercae)}

$$
\text { f. Percopsidae - trout-perches }
$$

Percopsis omiscomaycus (Walbaum) 1792 - trout-perch

Que., Ont., Man., Sask., Alta., B.C., NWT., Y.T., Alaska

Order PERCIFORMES (Percomorphi)

$$
\text { f. Serranidae - basses }
$$

Roccus comericanus (Gmelin) 1789 - white perch

N.S., P.E.I., N.B., Que., Ont.

Roccus chrysops (Rafinesque) 1820 - white bass

Que., Ont.

Roccus saxatilis (Walbaum) 1792 - striped bass

N.S., P.E.I., N.B., Que.

$$
\text { f. Centrarchidae - sunfishes }
$$

Ambloplites rupestris (Rafinesque) 1817 - rock bass Que., Ont., Man., Sask.

Lepomis auritus (Linnaeus) 1758 - redbreast sunfish N.B.

Formerly yellowbelly sunfish.

Lepormis cyanellus Rafinesque 1819 - green sunfish Ont.

Lepomis gibbosus (Linnaeus) 1758 - pumpkinseed N.B., Que., Ont., Man., B.C.*

Lepomis macrochims Rafinesque 1819 - bluegill

Que., Ont. 
Lepomis megalotis (Rafinesque) 1820 - longear sunfish Que., Ont.

Micropterus dolomieui Lacépède 1802 - smallmouth bass N.S.*, N.B.*, Que., Ont., Man.*, Sask.*, B.C.*

Micropterus salmoides (Lacépède) 1802 - largemouth bass Que., Ont., Man.*, Sask.*, B.C.*

Pomoxis connlaris Rafinesque 1818 - white crapple Ont.

Pomoxis nigromaculatus (Lesueur) 1829 - black crappie Que., Ont., Man., B.C.*

f. Percidae - perches

Amocrypta pellucida (Baird) 1863 - sand darter Que., Ont.

Etheostoma blennioides Rafinesque 1819 - greenside darter Ont.

Etheostoma caemulezon Storer 1845 - rainbow darter Que., Ont.

Etheostoma exile (G1rard) 1859 - Iowa darter Que., Ont., Man., Sask., Alta.

Etheostoma flabellare Rafinesque 1819 - fantall darter Que., Ont.

Etheostoma microperca Jordan and G1lbert 1888 - least darter Ont.

Etheostoma nigmom Rafinesque 1820 - Central Johnny darter Que., Ont., Man., Sask.

Etheostoma (Boleosoma) nigmom was represented in North America by three subspecies, all occurring in Canada: $E$. $n$. olmstedi Maritimes to eastern Lake Ontario; E. n. eulepis - Great Lakes basin; and $E$. n. nigmom - Saskatchewan to western Quebec. $E$. olmstedi Storer (as a full species) was proposed by Cole (1967) but 1 ts status in Canadian waters is 111 defined.

Perca flavescens (Mitch111) 1814 - yellow perch

N.S., N.B., Que., Ont., Man., Sask., Alta., B.C., NWT.

Formerly Perca fluviatilis Linnaeus 1758. Svetovidov and Dorofeeva (1963) synonymized the new and old world perches. $P$. flavescens is retained here, pending clarification. 
Percina caprodes (Rafinesque) 1818 - logperch

Que., Ont., Man., Sask.

Percina copelandi (Jordan) 1877 - channel darter

Que., Ont.

Percina maculata (Girard) 1859 - blackside darter

Ont., Man., Sask

Percina shumardi (Girard) 1859 - river darter

Ont., Man.

Stizostedion conadense (Smith) 1836 - sauger

Que., Ont., Man., Sask., Alta.

Stizostedion vitreron (Mitchill) 1818 - walleye

Que., Ont., Man., Sask., Alta., B.C., NWT.

Previous list showed the yellow walleye and the blue pike, Stizostedion vitrezon glauciom Hubbs 1926 as separate entities.

S. v. glaucum is now considered to be extinct.

f. Sciaenidae - drums

Aplodinotus gmoniens Rafinesque 1819 - freshwater drum Que., Ont., Man., Sask.

\section{f. Cottidae - sculpins}

Cottus aleuticus Gilbert 1893 - coastrange sculpin

B.C., Alaska

Formerly Aleutian sculpin.

Cottus asper Richardson 1836 - prickly sculpin

B.C., Alaska

Cottus bairdi Girard 1850 - mottled sculpin

Lab., Que., Ont., Man., Sask., Alta., B.C., NWT.

The species previously reported for B.C. as Cottus hubbsi

Bailey and Dimick 1949 has now been synonymized with C. bairdi (see Bailey and Bond, 1963).

Cottus cognatus Richardson 1836 - slimy sculpin

Lab., N.B., Que., Ont., Man., Sask., Alta., B.C., NWT., Y.T., Alaska

The species previously listed for B.C. as C. philonips Eigenmann and Eigenmann 1892, has been shown to be a synonym of C. cognatus (see McAllister and Lindsey 1959). 
Cottus confusus Bailey and Bond 1963 - shorthead sculpin

B. C.

Previously reported by McAllister and Lindsey (1961) as

Cottus sp. from the Flathead River, B.C. Its status as

a new species was clarified by Bailey and Bond (1963).

Cottus shotheus (Smith) 1882 - torrent sculpin

B.C.

Cottus micei (Nelson) 1876 - spoonhead sculpin

Que., Ont., Man., Sask., Alta., B.C., NWT., Y.T.

Myoxocephalus quadmicomis (Linnaeus) 1758 - deepwater sculpin Que., Ont., Man., Sask., NWT.

Formerly Triglopsis thompsoni (Girard) 1852. This species was for a time considered a subspecies, thompsoni of the species M. quadricomis. McAllister (1959b) gave evidence for elevating it to specific status, $M$. thompsoni. More recently, on the basis of possible intermediates in the Arctic the tendency is once more to call it a subspecies of $M$. quadricomis. Until its taxonomic position is clarified it seems appropriate to leave as above but to retain the distinctive common name. 


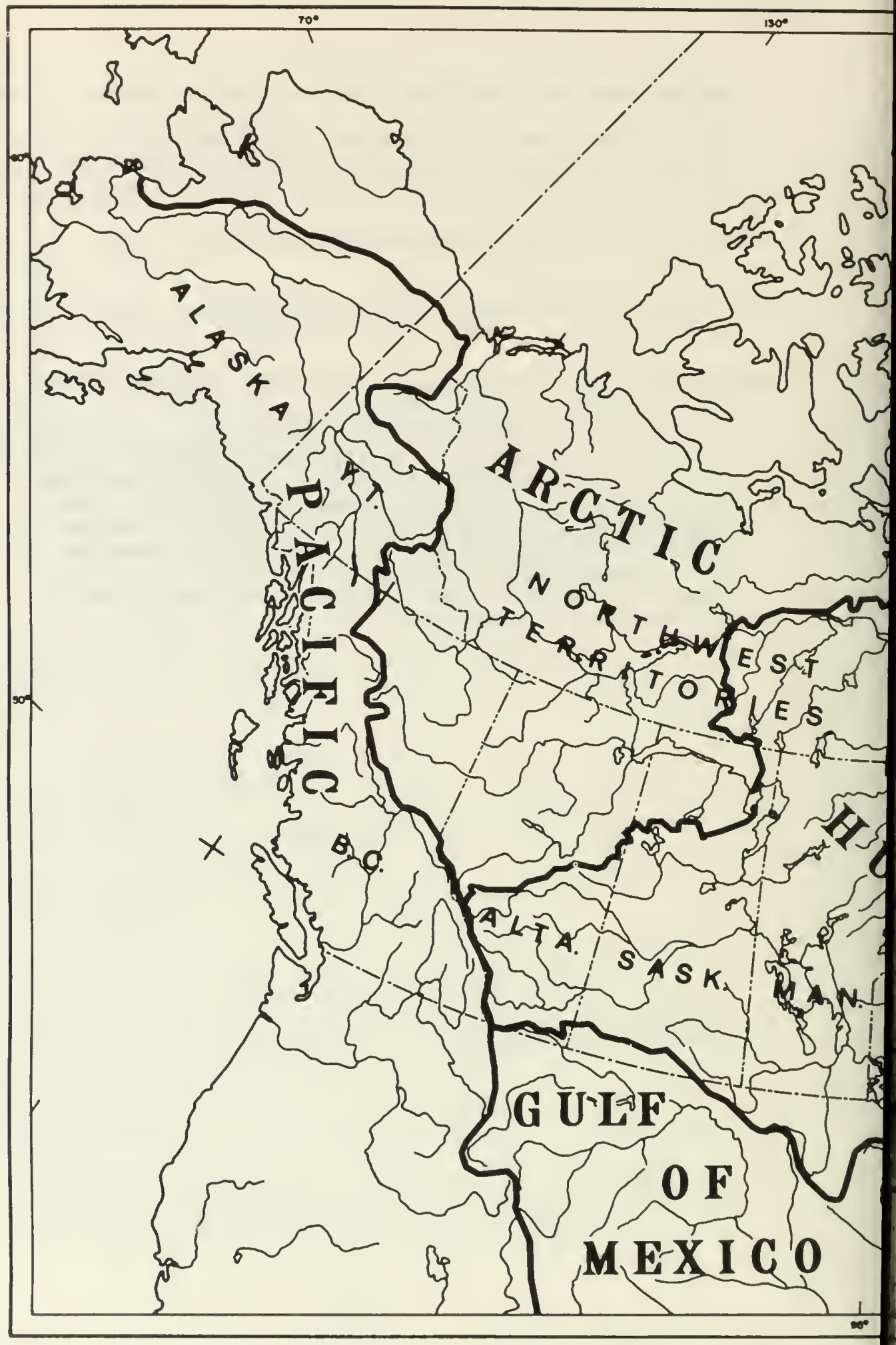




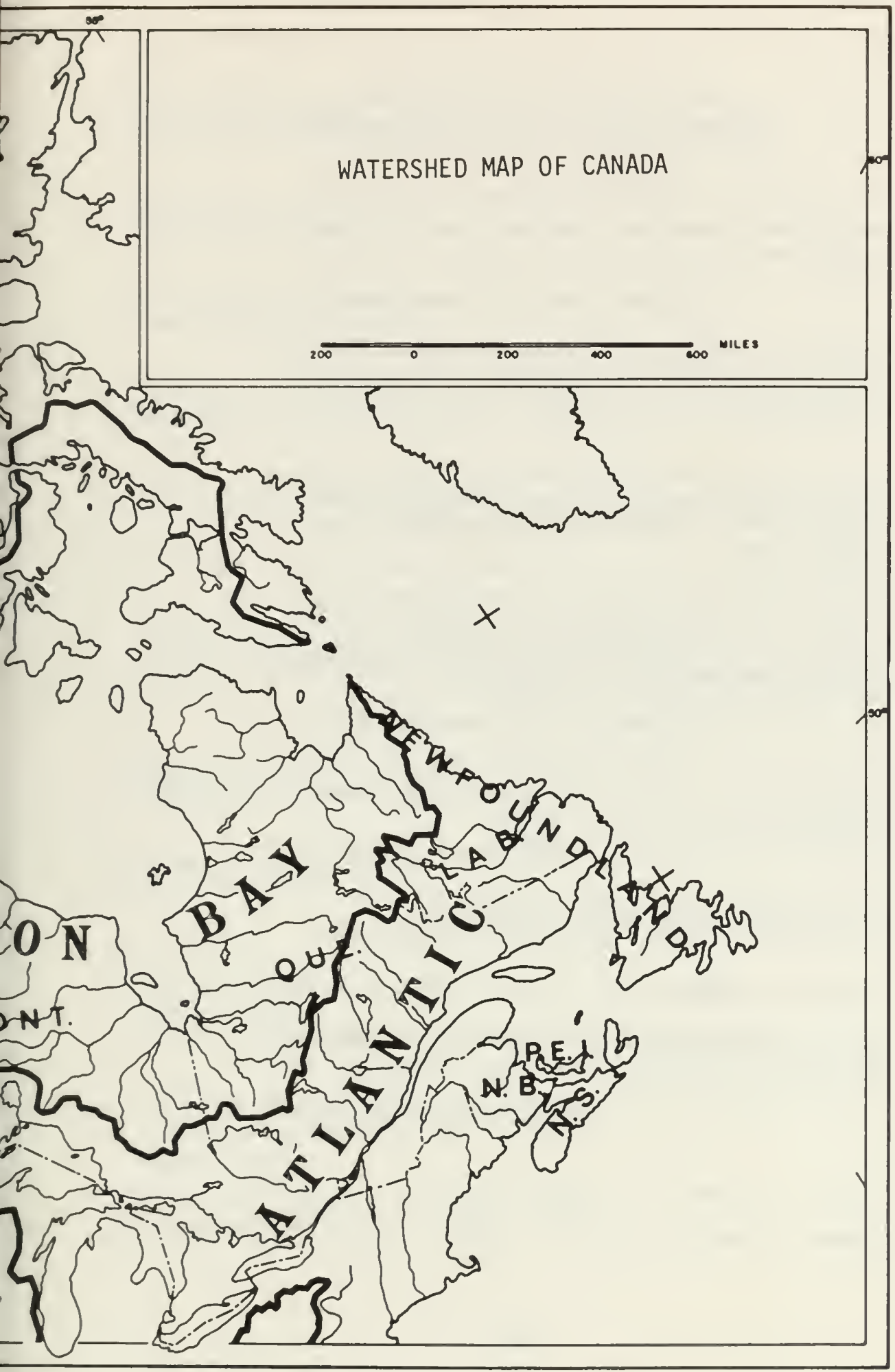




\section{KEY TO THE FAMILIES OF FISHES \\ OCCURRING IN THE FRESH WATERS OF CANADA}

1 Mouth without true jaws, instead a circular, suctorial disc; no paired fins; 7 pairs of gill openings.

Lampreys, family Petromyzontidae (p. 31)

Mouth with true jaws (i.e. upper and lower jaws present); with paired fins; opercles (or gill covers)

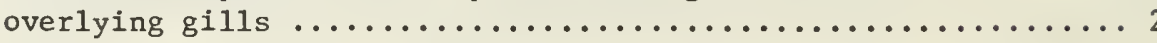

2 Upper and lower lobe of caudal (tail) fin, when present, of about equal size; body covering of overlapping scales or naked; no barbels before mouth;

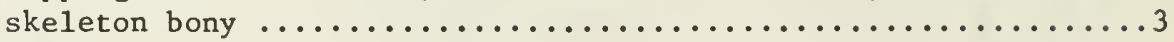

Upper lobe of caudal (tail) fin distinctly larger than.lower lobe; mouth inferior, snout well developed but not paddle-like; 5 rows of bony plates arranged longitudinally along body; 4 pairs of barbels before mouth.

Sturgeons, family Acipenseridae (p. 33)

3 Under surface of head, between lower jaws, with strong bony plate ("gular" plate). Bowfins, family Amiidae

Under surface of head (i.e. between the lower jaws) soft and not protected by large bony plate $\ldots \ldots \ldots \ldots \ldots \ldots 4$

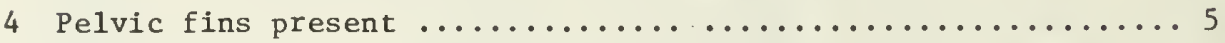

Pelvic fins absent, body cylindrical, long and snakelike; dorsal, caudal and anal fins continuous; no distinct caudal fin.

Eels, family Anguillidae

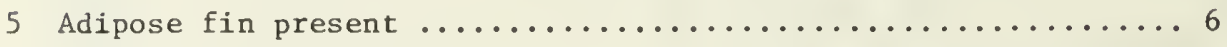

Adipose fin absent $\ldots \ldots \ldots \ldots \ldots \ldots \ldots \ldots \ldots \ldots \ldots \ldots \ldots \ldots \ldots \ldots \ldots \ldots \ldots$ 
6 Body scaleless; strong pectoral and dorsal spines;

long barbels about mouth.

Catfishes, family Ictaluridae (p. 59)

Body scaled, no strong spines in fins; no long

barbels about mouth ............................

7 Pectoral fin overlaps anterior pelvic base;

scales (weakly) ctenoid.

Trout-perch, family Percopsidae

Pectoral fin tip never reaches anterior base of

pelvic fin; scales cycloid ........................ 8

8 Pelvic axillary process absent.

Smelts, family Osmeridae (p. 42)

Pelvic axillary process present...................... 9

9 Mouth usually large, extending to middle of eye or beyond; teeth strong.

$$
\begin{aligned}
& \text { Salmons and trouts, } \\
& \text { (Salmoninae), family Salmonidae (p. 36) }
\end{aligned}
$$

Mouth usually small and not extending beyond middle of eye; teeth weak or absent ................... 10

10 Dorsal fin base shorter than head, dorsal rays 16 or fewer.

Whitefishes, ciscoes, (Coregoninae), family Salmonidae (p. 36)

Dorsal fin base longer than head, fin very high, rays 17 or more.

Grayling, (Thymallinae), family Salmonidae

11 Pelvic fins abdominal, or apparently so,

(posterior to pectoral fins, except

Gasterosteidae)

Pelvic fins thoracic or jugular (below

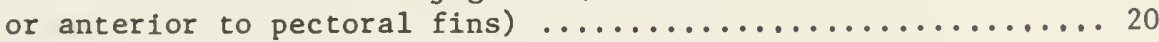


12 A single soft dorsal fin present, not preceded by spines

Soft dorsal fin preceded by 3-10 1solated spines or by a separate spiny dorsal or 4 slender, incon-

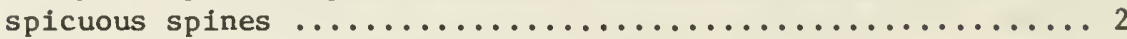

13 Body covered with thick, hard, glossy rhomboid scales.

$$
\text { Gar pikes, family Lepisosteidae (p. 34) }
$$

Body normally scaled or with scattered prickles or narrow plates

14 Gill membranes not attached to isthmus (gill open-

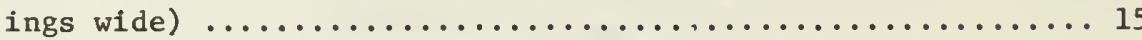

Gill membranes broadly joined to isthmus ( $\mathrm{g} i 11$ openings narrow

15 Head with some scales; body elongate; spotted, barred or dark coloured ......................... 16

Head without scales; body laterally compressed; silvery

16 Upper jaw protractile.

Killifishes, family Cyprinodontidae (p. 61)

Upper jaw not protractile

17 Jaws well developed; teeth strong; caudal fin forked.

$$
\text { Pikes, family Esocidae (p. 43) }
$$

Jaws short; teeth smal1; caudal fin rounded. Mudminnows, blackfish, family Umbridae (p. 43) 
18 Lips usually thick and mouth inferior, (except Ictiobus where it is oblique and with normal lips; however in Ictiobus the long dorsal fin has over 28 rays, and the longest unbranched ray is not a serrate, heavy, spine thus separating it from the two cyprinids with long dorsal rays, Cypminus and Carassius); pharyngeal teeth numerous and in one row, comb-like; swim bladder of 2 or 3 chambers.

Suckers, family Catostomidae (p. 54)

Lips thin, mouth seldom inferior, (except in Rhinichthys where scales are minute and much smaller than in suckers); dorsal fin long, no more than 22 rays and second unbranched element a heavy serrate spine; pharyngeal teeth in 2 or 3 rows, fewer than 9 per side; swim bladder of one chamber.

Minnows, family Cyprinidae (p. 45)

19 Lateral line absent; teeth absent, belly with sharp pointed scales; dorsal fin situated over pelvic fins and well in advance of anal fin; never more than 24 anal rays.

Herrings, family Clupeidae (p. 35)

Lateral line present, at times indistinct;

teeth present; no sharp, pointed scales on belly, belly fleshy instead; dorsal fin over anal fin and well behind pelvic fins; always more than 25 anal rays.

Mooneyes, family Hiodontidae (p. 43)

20 Body plated, naked or with prickles; pectoral fins large and conspicuous. Sculpins, family Cottidae (p. 72)

Body scaled (scales small and somewhat embedded in Gadidae); pectoral fins of moderate size,

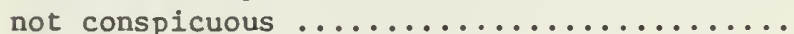


21 Chin with small but distinct median barbel.

Cods, family Gadidae (p. 62)

Chin without small median barbel $\ldots \ldots \ldots \ldots \ldots \ldots \ldots \ldots \ldots$

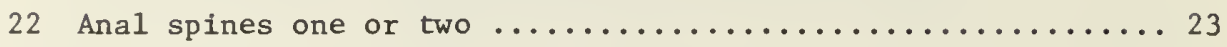

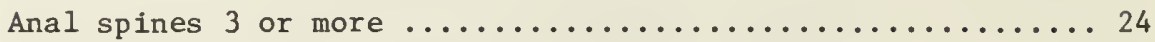

23 Second anal spine strong and stout and conspicuously larger than first; lateral line extending on to caudal fin.

Drums, family Sciaenidae

Second anal spine slender and not conspicuously

larger than first; lateral line not extending onto caudal fin.

$$
\text { Perches, family Percidae (p. 67) }
$$

24 Opercle with a spine; 3 anal spines; pseudobranch well developed and obvious.

Basses, family Serranidae (p. 63)

Opercle without a spine; 3 or more anal spines; pseudobranch concealed or absent.

Sunfishes, family Centrarchidae (p. 64)

25 Strong pelvic spines present; caudal fin rounded or slightly forked.

Sticklebacks, family Gasterosteidae (p. 62)

Pelvic fins without spines; caudal fin forked.

Silversides, family Atherinidae 
1 Dorsal fin composed of two obvious lobes; lobes separated, or joined by very low and inconspicuous

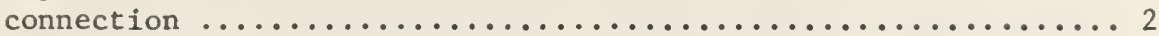

Dorsal fin single but notched, notch never reaching dorsal surface of body $\ldots \ldots \ldots \ldots \ldots \ldots \ldots \ldots \ldots \ldots \ldots . \ldots . \ldots$

2 Supraoral teeth on broad curved bar (lamina) .............

Supraoral teeth not on broad curved bar (lamina) but consisting of a single, median, large, bicuspid tooth, with pointed cusps; laterals 4, bicuspid, pointed cusps; trunk myomeres 67-74; parasitic; to $860 \mathrm{~mm}$ in length.

Sea lamprey, Petromyzon maminus

3 Supraoral lamina with 2 lateral cusps, no median

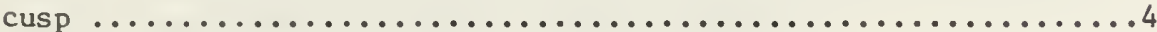

Supraoral lamina with 3 prominent, sharp cusps, one median; lateral teeth 3 or 4 with at least the middle 2 on each side tricuspid, others bicuspid, or tricuspid; semicircular row of small teeth below infraoral bar; trunk myomeres 64-74; parasitic; to $680 \mathrm{~mm}$ in length.

Pacific lamprey, Lampetra tridentata

4 Inner lateral teeth bicuspid or tricuspid .............. 5

Inner lateral teeth 3, unicuspld, prominent, conical, blunt; infraoral bar with 6-8, blunt, rounded teeth; trunk myomeres 70-74; parasitic; to $280 \mathrm{~mm}$ in total length.

Arctic lamprey, Lampetra joponica

* This key is intended only for transformed individuals. The identification of immature lampreys (larvae or ammocoetes, with an oral hood) requires much more detail. 
5 Inner lateral teeth 3 , at least middle one on both

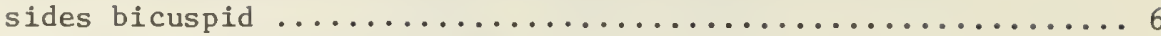

Inner lateral teeth 3 , at least middle tooth on both sides tricuspid (rarely middle lateral on one or both sides tricuspid in Lampetra richardsoni).........7

6 Inner lateral teeth prominent, bluntly pointed, all bicuspid; teeth above supraoral bar prominent, sharply pointed; tongue with sharp teeth; trunk myomeres 64-70; non-parasitic; length to $187 \mathrm{~mm}$. American brook lamprey, Lampetra lamottei

Inner lateral teeth poorly defined, knob-like, some may be unicuspid; teeth above supraoral bar (anterials), if apparent, very small and peg-like; no sharp teeth on tongue; trunk myomeres 60-70; non-parasitic; length to $154 \mathrm{~mm}$. Western brook lamprey, Lompetra michardsoni

7 Teeth-above supraoral lamina (anterials) prominent and sharp; sharp teeth on tongue; trunk myomeres 63-71; parasitic; length to $311 \mathrm{~mm}$.

River lamprey, Lampetra ayresi

Teeth above supraoral lamina (anterials), if apparent, very small and peg-like; no sharp teeth on tongue; trunk myomeres 60-70; nonparasitic; length to $154 \mathrm{~mm}$.

Western brook lamprey, Lampetra micharäsoni

8 Lateral teeth all unicuspid $\ldots \ldots \ldots \ldots \ldots \ldots \ldots \ldots \ldots \ldots \ldots$

At least one or more bicuspid inner lateral teeth on each side, supraoral a single sharp bicuspid tooth; trunk myomeres 50-56; parasitic; to $380 \mathrm{~mm}$ in length.

Chestnut lamprey, Ichthyomyzon castaneus 
9 Supraoral usually a single bicuspid tooth (one cusp rarely doubled), cusps sharp; infraoral lamina with prominent triangular cusps; diameter of sucking disc greater than that of branchial region; trunk myomeres 47-55; parasitic; length to $328 \mathrm{~mm}$.

Silver lamprey, Ichthyomyzon unicuspis

Supraoral a single weak bicuspid tooth, cusps knob-like; infraoral lamina with low knob-like cusps; diameter of sucking disc less than that of branchial region; trunk myomeres 50-58; nonparasitic; length to $150 \mathrm{~mm}$.

Northern brook lamprey, Ichthyomyzon fossor

KEY TO THE SPECIES OF THE FAMILY ACIPENSERIDAE

1 Obvious plates other than fulcral plates between dorsal fin and caudal fin, and between anal fin

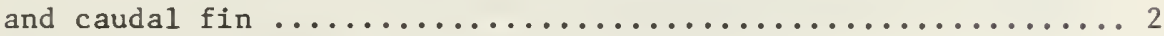

No obvious plates behind dorsal or anal fin other than fulcral plates; 6-9 plates, mainly in two rows, between vent and anal fulcral; dorsal plates 11-14; lateral plates 38-48; to $20 \mathrm{ft}$. and $1800 \mathrm{lb}$. White sturgeon, Acipenser transmontanus

2 One large plate between anal fin and caudal

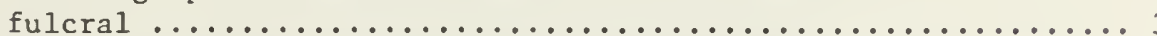

Four smaller plates usually as two pairs, between anal fin and caudal fulcral, first pair may overlap base of anal fin, second pair may look like one plate; 6-9 plates, mostly in pairs, behind dorsal fin; dorsal plates 10-16; lateral plates 26-34; to $10 \mathrm{ft}$. and $300 \mathrm{lb}$. Atlantic sturgeon, Acipenser oxyrhynchus 
3 Distance from tip of snout to line of barbels equal to or slightly less than one half the distance from tip of snout to anterior edge of mouth, lip excluded; snout to barbels no more than 1.5 times distance from posterior margin of mouth, lips excluded, to isthmus; g111 rakers $22-40 \ldots \ldots \ldots \ldots \ldots \ldots \ldots \ldots \ldots \ldots \ldots \ldots \ldots \ldots$

Distance from tip of snout to line of barbels more than one half the distance from tip of snout to anterior edge of mouth, lip excluded; snout to barbels over twice the distance from posterior edge of mouth, 1ip excluded, to isthmus; gill rakers 18-20; dorsal plates 8-11; lateral plates 23-30; to $7 \mathrm{ft}$. and 350 1b.

Green sturgeon, Acipenser medirostris

4 Anal fin rays 25-30; insertion of anal fin plainly behind insertion of dorsal fin; gill rakers $25-40$ but usually 32-35; caudal peduncle longer, tip of anal fin reaching only to anterior edge of caudal fulcral plate; dorsal plates 9-17; lateral plates $29-42$; to $7 \mathrm{ft}$. and $350 \mathrm{lb}$.

Lake sturgeon, Acipenser fulvescens

Anal fin rays 19-22; insertion of anal fin opposite insertion of dorsal fin; gill rakers 22-29; caudal peduncle shorter, tip of anal fin reaching origin of caudal fin; dorsal plates $8-11$; lateral plates 22-33; to 36 Inches and $91 \mathrm{~b}$.

Shortnose sturgeon, Acipenser brevirostmon

KEY TO THE SPECIES OF THE FAMILY LEPISOSTEIDAE

1 Snout long and narrow, least snout width into snout length 14-18 times; caudal peduncle shallow and long, least depth into length 2.3-2.9 times; lateral line 
scales 61-65; spots on body apparent only from pelvic fin to caudal peduncle, spots on dorsal, anal and caudal fins.

\section{Longnose gar, Lepisosteus osseus}

Snout short and broad, least snout width into snout length 6-8 times; caudal peduncle deeper and shorter, depth into length $1.7-2.0$ times; lateral line scales 46-50; body, head and all fins conspicuously spotted on epidermal layer over scales.

Spotted gar, Lepisosteus productus

KEY TO THE SPECIES OF THE FAMILY CLUPEIDAE

1 Last ray of dorsal fin protracted into a long filament; snout rounded, mouth slightly subterminal; anal rays more than 25 .

Gizzard shad, Dorosoma cepedianzon

Last ray of the dorsal fin the shortest ray; snout more or less pointed; mouth terminal; anal rays

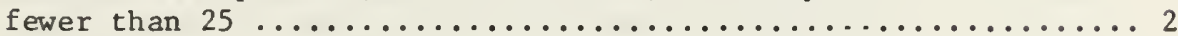

2 Lower jaw, when closed, nearly equal to upper, and fits into notch in upper jaw; maxillary extends at least to posterior margin of eye; gill rakers more than 55 ; usually $4-6$ black spots in horizontal row behind operculum.

American shad, AZosa sopidissima

Lower $\mathrm{jaw}$, when closed, extending beyond upper jaw; maxillary extends only to midpoint of eye; gill rakers fewer than 55; one prominent black spot near upper rear edge of operculum ................. 3

3 Eye diameter usually greater than snout length; peritoneum silvery.

Alewife, Azosa pseudoharengus

Eye diameter usually smaller than snout length; peritoneum darkly pigmented.

Blueback herring, Alosa aestivalis 
1 Scales small, those in lateral line 115-200; teeth well developed on jaws and vomer; caudal usually truncate, occasionally forked; young (6 inches or less) with dark vertical blotches (parr marks) on sides (except 0 . gorbuscha)

Salmons, trouts, chars (Salmoninae) ............... 2

Scales large, those in lateral line 100 or less;

teeth weakly developed or absent; caudal fin

distinctly forked; parr marks usually absent

(except Prosopium and Thymallus); colour gener-

ally silvery, silvery green, or silvery blue.

Whitefishes (Coregoninae) and grayling (Thymallinae) ..... 14

2 Anal rays 13-19 (usually 14-16); body and

caudal fin of adults with black spots.

Pacific salmons, Oncorhynchus spp. ............... 10

Anal rays 7-12 (usually 9-11); body and caudal fin with or without black spots $\ldots \ldots \ldots \ldots \ldots \ldots \ldots \ldots$

3 Black spots present on head and body

(young $S$. salar have red spots between parr marks); scales conspicuous, fewer

than 165 in lateral line; pelvic and anal

fins without white leading edges; vomer

flat with teeth extended backward in 2 rows $\ldots \ldots \ldots \ldots \ldots \ldots \ldots$

Light spots, not black spots, on body, these

spots being pink, red, or cream in colour;

scales not conspicuous; lower fins with

snow-white leading edges; vomer boat-shaped,

teeth on the anterior part only $\ldots \ldots \ldots \ldots \ldots \ldots \ldots \ldots \ldots \ldots$

* When in the sea, or in large lakes, body pigmentation is usually masked by heavy silvery colouration. The characters enumerated in the key will be evident if the specimen is examined carefully. 
4 Caudal fin distinctly marked with radiating rows of black spots; body never with red spots; adipose often with black margin; scale rows $120-$

Caudal fin usually unspotted, but never with regular rows of black spots; reddish spots sometimes on body; scale rows usually $110-130 \ldots \ldots \ldots \ldots \ldots \ldots \ldots$

5 Red or orange-red dash on lower $j a w$, along inner border of mandible; minute teeth usually present at base of tongue (basibranchial teeth). Cutthroat trout, Salmo clarki

No red colouration present on lower jaw; minute teeth at base of tongue absent.

Rainbow trout, Salmo gairaneri

6 Maxillary to below centre of eye in 6-inch fish, seldom far behind eye (except in large males); gill cover with 2 or 3 large spots only; branchiostegals usually 12; dorsal fin rays usually 11 ; vomerine teeth usually not well developed; small fish have red spots between parr marks; no red on adipose fin.

Atlantic salmon, Salmo salar

Maxillary to below last half of eye on 5-inch fish, and extending well beyond eye in larger fish; gill cover usually with many spots; branchiostegals usually 10; dorsal fin rays usually 9; vomerine teeth well developed; rust-red spots sometimes on adults and often on margin of adipose fin.

$$
\text { Brown trout, Salmo trutta }
$$

7 Caudal fin deeply forked; dorsal and caudal fins, body and head covered with small, often beanshaped light spots, body never brightly coloured 
with orange or red; parr marks quite irregular, and narrow; pyloric caecae over 90 .

Lake trout, Salvelinus namaycush

Caudal fin square (truncate) or slightly forked, body with light-coloured spots of cream, pink, or red; dorsal and caudal fins with dark wavy lines and marks, or unspotted, without light spots;

pyloric caecae less than $75 \ldots \ldots \ldots \ldots \ldots \ldots \ldots \ldots \ldots \ldots \ldots$

8 Caudal fin square or nearly so; dorsal and caudal fins with distinct, dark wavy lines or blotches; lower fins with pure white leading edges usually followed by black; back usually with wavy lines (vermiculations); sides with pink or red spots, many of which have blue borders; young with 8-10 regularly arranged parr marks on sides.

Brook trout, Salvelinus fontinalis

Caudal fin nearly square or slightly forked, (may be deeply forked in freshwater populations in eastern (anada) without dark wavy lines on dorsal and caudal fins; lower fins with pure white leading edges, but not usually followed by black; sides with creamy, pink, or reddish spots, not extending onto fins; parr marks vague or irregular, not well

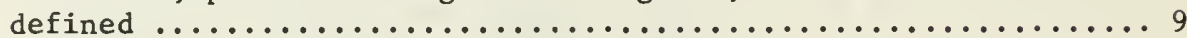

9 Spots usually large and less numerous; gill rakers on upper limb of first gill arch 7-13, on lower limb 12-19; pyloric caecae 20-74. Arctic char, Salvelinus alpinus

Spots round, sma11, and numerous; gil1 rakers on upper limb of first gill arch $3-9$, on lower limb 8-14; pyloric caecae 13-47.

Dolly Varden, Salvelinus malma

10 Distinct black spots on back and on caudal fin ........... 11

No distinct black spots on back or caudal fin but fine black speckling may be present ..................... 13 
11 Large black spots on back and caudal fin, the largest as large as eye; scales smal1, 169-229 in first row above lateral line; gill rakers 26-34.

Pink salmon, Oncorhynchus gorbuscha

Spots on back and caudal fin small, largest as large as pupil of eye; scales moderate, fewer than 154 in first row above lateral

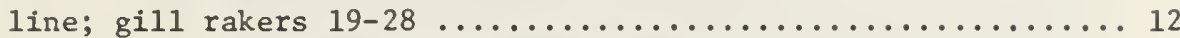

12 Small black spots on both lobes of caudal fin; flesh at base of teeth of lower jaw black; pyloric caecae 140-185; gill rakers 20-28. Chinook salmon, Oncorhynchus tshoarytscha

Small black spots when present on tail on upper lobe only; flesh at base of teeth of lower jaw pale; pyloric caecae 45-80; gill rakers 19-25.

Coho salmon, Oncorhynchus kisutch

13 Gill rakers on first arch $30-40$, long, slender and crowded; pyloric caecae 60-115. Sockeye salmon (or kokanee), Oncorhynchus nerka

G111 rakers on first arch 19-26, short, stout and widely spaced; pyloric caecae 140-186.

Chum salmon, Oncorhynchus keta

14 Dorsal fin base equal to or longer than head, dorsal fin usually with more than 17 rays, fin large and sail-like on fishes 8 inches or larger; colour of back bluish or purple, dorsal and pelvic fins sometimes with green or reddish spots.

Arctic grayling, Thymallus arcticus

Dorsal fin base shorter than head, dorsal fin rays fewer than 17; dorsal fin not expanded; colour usually silvery, back sometimes black, blue, or green.

Whitefishes (Coregoninae) 
15 A single small flap of skin between nostrils; snout pinched, rather pointed, mouth inferior; gill rakers stout, short, usually $13-20$ but to 26 in Alberta and British Columbia.

Round whitefishes, Prosopizon spp............... 16

Two small flaps of skin between nostrils, snout not pinched but usually somewhat broad; mouth inferior, overhung by snout, or mouth terminal, lower jaw may be projecting beyond upper; gill rakers generally long and slender, more than 22

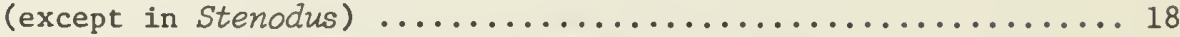

16 Gill rakers 20-25 (rarely 26); scales around caudal peduncle in 20-23 rows.

Mountain whitefish, Prosopizon williamsoni

Gi11 rakers $13-20$

17 Lateral line scales 85-100; scales around

caudal peduncle 22-24; pyloric caecae 50-117. Round whitefish, Prosopizm cylindracerm

Lateral line scales 55-70; scales around caudal peduncle 18-20; pyloric caecae 15-23.

Pygmy whitefish, Prosopium coulteri

18 Mouth inferior, overhung by snout; premaxil1aries retrorse; gill rakers usually fewer than 32

Upper and lower jaws nearly equal, or lower jaw projecting; premaxillaries antrorse; gill rakers usually more than 32 (except Stenodus)

19 Gill rakers 19-25, short; maxillary short and broad, its length less than twice its width; lower fins thick, opague, of ten with bluish cast in 1 ife.

\section{Broad whitefish, Coregonus nasus}

Gi11 rakers 23-33, 1ong; maxillary longer, its length twice or more the width; lower fins not 
especially thick, transluscent, often sprinkled with dark chromatophores $\ldots \ldots \ldots \ldots \ldots \ldots \ldots \ldots \ldots \ldots \ldots \ldots . \ldots \ldots$

20 Scales in lateral line less 90 (70-85); mouth inferior, obviously overhung by snout; minute teeth on premaxillaries, palatines and vomer of juveniles only (under $100 \mathrm{~mm}$ long). Lake whitefish, Coregonus clupeaformis

Scales in lateral line more than 90 (91-100); mouth terminal or nearly so; teeth on premaxillaries, palatines and vomer, small but present even on adults.

Undescribed whitefish in Nova Scotia Coregonus sp.

21 Body shape pike-like; lower jaw distinctly projecting; gill rakers 19-24; scales, small, 97-110 in lateral line.

Inconnu, Stenodus Zeucichthys

Body shape herring-like; upper and lower jaws equal or nearly so (lower jaw may project slightly); gill rakers more than 32 (commonly 40 or more); scales larger, usually 65-85 (Coregonus autronnalis, 86-111).

Subgenus Leucichthys, 12 species*

Numerous keys to the species of the subgenus Leucichthys have been attempted. All of them are unsatisfactory because of the excessive phenotypic plasticity of the ciscoes, hence no attempt to separate them is made here. The most variable and wide ranging species is $C$. artedii. 
1 Gill rakers on upper half of arch 4-6; pyloric caecae 8-11; scales in latera1 line 70-78, lateral line complete; pronounced concentric marks on operculum.

Eulachon, Thaleichthys pacificus

Gil1 rakers on upper half of arch 8-14; pyloric caecae 0-6; scales in lateral line 65 and fewer, lateral line incomplete; no obvious concentric

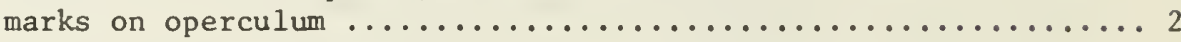

2 Maxillary extending only to middle of pupil; tongue teeth minute and villiform; pyloric caecae 0-3; snout somewhat rounded; rarely over $120 \mathrm{~mm}$.

Pond smelt, Hypomesus olidus

Maxillary extending beyond pupil, usually to posterior margin of eye; tongue teeth from medium conical to large canine; pyloric caecae 4-11; snout more pointed; size larger ................... 3

3 Gill rakers on lower half of arch 27-34, total gill rakers usually over 37 ; anal rays usually 16-18; base of anal fin more than 3 times eye diameter; no enlarged teeth on tongue; rarely over $135 \mathrm{~mm}$.

Longfin sme1t, Spirinchus thaleichthys

Gill rakers on lower half of arch 18-24, total gill rakers usually under 37; anal rays usually fewer than 16; base of anal fin about 2.5 times eye diameter; one or two prominent, curved canine teeth on tip of tongue larger; size large to $324 \mathrm{~mm}$.

Rainbow smelt, Osmerus eperlanus 
1 Ventral surface keeled from isthmus to anal fin; origin of dorsal fin opposite or behind origin of anal fin; maxillary extends beyond middle of pupil.

Goldeye, Hiodon alosoides

Ventral surface keeled from pelvic fins to anal fin; origin of dorsal fin well ahead of origin of anal fin; maxillary short of, or just to, middle of pupil.

Mooneye, Hiodon tergisus

KEY TO THE SPECIES OF THE FAMILY UMBRIDAE

1 Pelvic fin small, half as long as pectoral; anal fin of 11 or 12 rays with base about as long as base of dorsal; area between dorsal and anal with blotches; caudal fin spotted.

Blackfish, Dallia pectoralis

Pelvic fin large, as long as pectoral; anal fin of 8 or 9 rays with base about half as long as base of dorsal; area between anal and dorsal with vague, vertical bars; prominent vertical black bar at base of caudal; caudal fin not spotted.

Central mudminnow, Umbra limi

KEY TO THE SPECIES OF THE FAMILY ESOCIDAE

1 Submandibular pores 10 or more; cheeks and/or

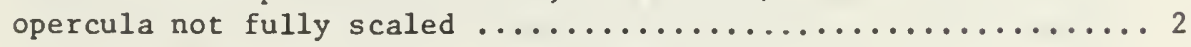

Submandibular pores 8 or fewer (rarely 9); both cheeks and opercula more or less fully

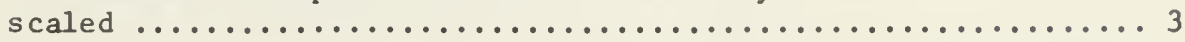


2 Submandibular pores 12-20; branchiostegal rays 16-19, most often $8+10$ on each side*; pattern silvery or light ground colour with dark spots, blotches, or vertical stripes; neither cheeks nor opercula completely scaled.

Muskellunge, Esox masquinongy

Submandibular pores 10-11 (rarely 9); branchiostegal rays $13-16$, most often $7+8$ on each side; pattern dark ground colour with wavy vertical stripes in young, or horizontal rows of bean-shaped spots in adults; cheeks fully scaled, opercula not so.

Northern pike, Esox Zucius

3 Submandibular pores 7 or 8 (rarely 9) and branchiostegal rays 14-17, most often $6+9$ on each side; colour pattern dark ground coat with wavy, vertical stripes in young and golden chain-like markings in adults.

Chain pickerel, Esox niger

Submandibular pores 7 or 8 and branchiostegal

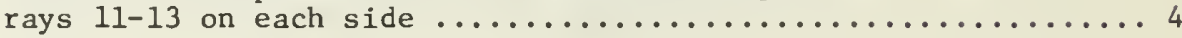

4 Branchiostegal rays usually $5+7$ or $5+8$ on each side; snout short, convex in upper profile; cardioid scales between pelvics more than 5 , and more than 5 in a line from origin of anal fin to dorsal surface; lower fins red to orange.

Redfin pickerel, Esox a. americanus

Branchiostegal rays usually $4+7$ or $4+8$ on each side; snout longer and concave in upper profile; cardioid scales between pelvics fewer than 5 , and fewer than 5 in a line from origin of anal fain to dorsal surface; lower fins dusky to yellow-green. Grass pickerel, Esox a. vermiculatus

* 8 on ceratohyal, 10 on epihyal 
1 Dorsal fin base long, more than 11 soft rays; dorsal and anal fins each with strong spine,

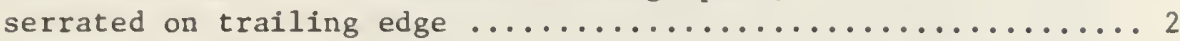

Dorsal fin base short, fewer than 11 rays; no spines in fins (except Acrocheilus aleuticus and Richardsonius balteatus which may occasion-

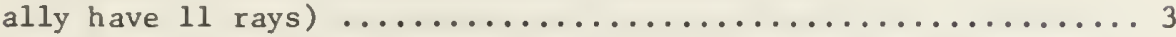

2 Two pairs of long barbels on upper jaw; pharyngeal teeth molar-like $(1,1,3-3,1,1)$; gill rakers 21-27; scales in lateral line usually more than 32 (mirror and leather carp are only partially scaled).

Carp, Cyprinus carpio

Barbels absent; pharyngeal teeth not molar-like $(4-4)$; gill rakers 37-43; scales in lateral line usually less than 32 .

Goldfish, Carassius auratus

3 Premaxillaries not protractile (i.e. no groove

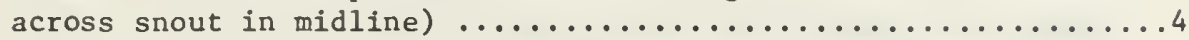

Premaxillaries protractile (i.e. with groove

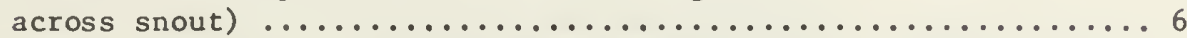

4 Lower jaw conspicuously trilobed, its centre lobe tongue-shaped; body stout; caudal peduncle deep.

Cutlips minnow, Exoglossum maxillingua

Lower jaw of normal shape; body flecked with darkened scales or speckled; body streamlined;

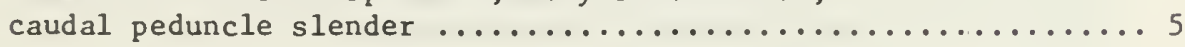


5 Snout long, projecting far beyond mouth;

lateral band indistinct or absent.

Longnose dace, Rhinichthys cataractae

Snout scarcely projecting beyond mouth;

lateral band prominent; rusty-red lateral

band on spawning males.

Blacknose dace, Rhinichthys atratulus

6 Maxillary with barbel (sometimes concealed

in $\operatorname{maxillary}$ groove) $\ldots \ldots \ldots \ldots \ldots \ldots \ldots \ldots \ldots \ldots \ldots \ldots \ldots \ldots$

Maxillary without a barbel $\ldots \ldots \ldots \ldots \ldots \ldots \ldots \ldots \ldots \ldots \ldots$

7 Barbel terminal and slender, at or near end of maxillary .................................. 8

Barbel in front of posterior end of upper jaw,

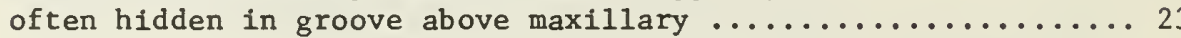

8 Scales in lateral line very small, 90 or more;

body deep, about $25 \%$ of total length .

Tench, Tinca tinca

Scales in lateral 1ine fewer than 80 ; body

depth moderate, $20 \%$ or less of total length ............... 9

9 Mouth large, gape extending to below anterior margin of eye; pectoral fins long, narrowed, and pointed, the tips reaching to anterior base of pelvic fins or nearly so;

lateral line scales 48-59.

Flathead chub, Platygobio gracizis

Mouth moderate to small, gape not extending to anterior margin of eye; pectoral fins rounded or bluntly pointed, not reaching

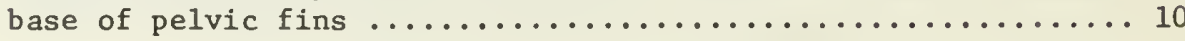


Lateral line scales less than 50

11 Lateral line scales 68-79; pelvic axillary scale well developed.

Peamouth chub, Mylocheilus cauminum

Lateral line scales 52-65; pelvic axillary scale absent or weakly developed...

12 No fleshy stays on dorsal aspect of pelvic fins; lateral line scales 54-65; body sometimes with specialized darkened scales.

Lake chub, Couesius plrombeus

Conspicuous tileshy stays on dorsal aspect of pelvic fins, joining fin rays to body; body conspicuously speckled; lateral line scales 52-57.

Leopard dace, Rhinichthys falcatus

13 Snout projecting only slightly beyond mouth ............ 14

Snout projecting considerably beyond mouth $\ldots \ldots \ldots \ldots \ldots \ldots \ldots$

14 Angle enclosed by scale radii about $70^{\circ}-75^{\circ}$; caudal spot large and distinct; snout length into standard length more than 9 times; distinct mid-dorsal line and lateral band. Hornyhead chub, Nocomis biguttatus

Angle enclosed by scale radii $95^{\circ}-105^{\circ}$; no caudal spot; snout length into standard length 8 or less; no mid-dorsal line; 1ateral band indistinct.

River chub, Nocomis micropogon 
15 Body with X-shaped dark spots.

Spotted chub, Hybopsis $x$-pronctata

Body without definite spots; scales large and deciduous; lower 3 or 4 rays of caudal fin unpigmented.

Silver chub, Hybopsis storemiana

16 Lateral line scales more than $55 \ldots \ldots \ldots \ldots \ldots \ldots \ldots \ldots \ldots$

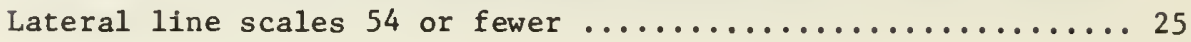

17 Mouth terminal, not overhung by snout; gape

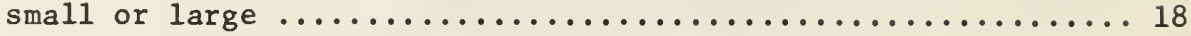

Mouth inferior, overhung by snout; gape

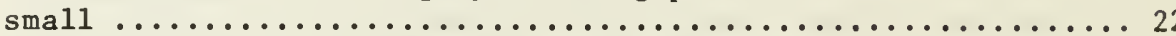

18 Peritoneum black; lateral line incomplete;

body robust, not noticeably compressed; size

small, to about $76 \mathrm{~mm}(3$ inches) $\ldots \ldots \ldots \ldots \ldots \ldots \ldots \ldots \ldots$

Peritoneum silvery or speckled, not black;

lateral line complete; body laterally com-

pressed or elongate and pike-like; size

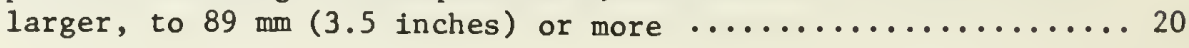

19 Intestine with 2 crosswise colls in addi-

tion to main loop; mouth small, terminating

distinctly in advance of eye; a dark line, entire or broken, between lateral band and back.

Redbelly dace, Chrosomus eos

Intestine shorter, with single main loop;

mouth larger, extending almost to below

anterior margin of eye; back uniformly

pigmented.

Finescale dace, Chrosomus neogaeus 
20 Pelvic fin origin not in advance of dorsal fin, dorsal inserted over pelvic fin origin; body elongate, not markedly compressed; young with small but precise black spot at caudal base.

Squawfish, Ptychocheilus oregonense

Pelvic fin origin in advance of dorsal fin origin; body laterally compressed; no black

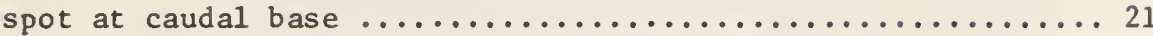

21 Dorsal rays 9 or 10 (seldom 8); anal rays 10-22, usually 15; snout short, less than eye diameter.

Redside shiner, Richardsonius balteatus

Dorsal rays 8; anal rays 9 (seldom 10); snout long and pointed, greater than eye diameter. Redside dace, Clinostomus elongatus

22 Lower jaw with a hard and almost straight cutting edge (like a chisel); anal rays 9; peritoneum jet black. Chiselmouth, Acrocheilus alutacerm

Lower $j$ aw with fleshy lip, mouth sucker-1ike; anal rays 7 ; peritoneum dark brown. Speckled dace, Rhinichthys osculus

23 Scales in lateral line fewer than 50; young with distinct mid-lateral black band; each scale with dense pigment anteriorly. Fallfish, Semotilus corporalis

Scales in lateral line more than 50; scales without black pigment anteriorly

24 A black spot near anterior base of dorsal fin, sometimes indistinct in young; upper jaw extending to vertical through front of eye; lateral 
line scales 52-62; silvery, no distinct spawning colour.

Creek chub, Semotilus atromaculatus

No black spot on dorsal fin; upper jaw not

reaching a vertical through front of eye;

barbel often small or absent; lateral line

scales 65-75; sides often with scattered,

darkened scales; spawning males with red on

flanks and belly.

Pearl dace, Semotilus margarita

25 Abdomen behind pelvic fins with a fleshy keel

lacking scales; lateral line strongly decurved, following ventral outline of body; anal fin rays 12 or 13 .

Golden shiner, Notemigonus crysoleucas

Abdomen behind pelvic fins rounded over and scaled; lateral line not strongly decurved; anal fin rays usually less than $12 \ldots \ldots \ldots \ldots \ldots \ldots \ldots \ldots \ldots$

26 A dark spot (sometimes faint) at front of dorsal fin, slightly above base; back flattish; first dorsal ray separated by membrane from first well-developed ray; pre-dorsal scales

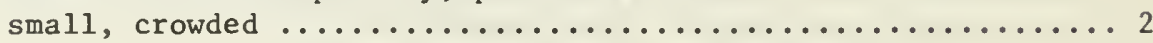

No dark spot at front of dorsal fin above base (a dark pigmented area at anterior base in Notropis combratilis); back scarcely flattened; first dorsal ray closely attached to first well-developed ray; pre-dorsal scales usually

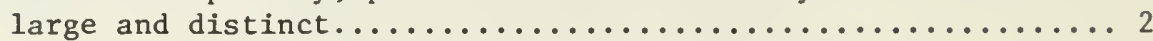

27 Lateral line incomplete; caudal spot faint; mouth terminal but small.

Fathead minnow, Pimephales promelas

Lateral line complete; a distinct caudal spot; mouth subterminal.

Bluntnose minnow, Pimephales notatus 
28 Mouth very small and nearly vertical; dorsal fin rays typically 9.

Pugnose minnow, Opsopoeodus emiliae

Mouth larger; dorsal fin rays typically $8 \ldots \ldots \ldots \ldots \ldots . \ldots 29$

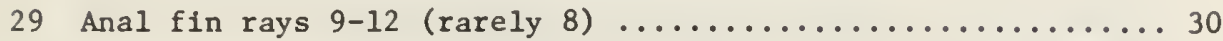

Anal fin rays 7 or 8 (rarely 9$) \ldots \ldots \ldots \ldots \ldots \ldots \ldots \ldots \ldots \ldots \ldots \ldots$

30 Origin of dorsal fin over, or in front of, vertical through insertion of pelvic fins;

lateral scales twice as high as wide; lower

fins of males red during spawning.

Creek shiner, Notropis comutus*

Origin of dorsal fin behind vertical through

insertion of pelvic fins; scales round or

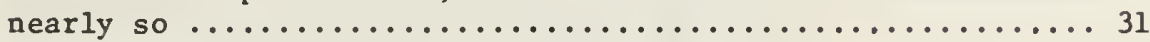

31 Body deep, depth equal to or more than length of head; dorsal fin with black pigmented area at anterior base; sides stippled with pigment; spawning males have bluish body, and rosy lower fins.

Redfin shiner, Notropis umbratilis

Body slender, depth much less than length of head; no black spot at base of dorsal fin ............. 32

* $N$. chrysocephalus has been described as a species distinct from $N$. comutus; chin usually pigmented; pre-dorsal, dorso-lateral scale rows 13-16 in chrysocephalus; chin usually unpigmented; predorsal, dorso-lateral scale rows 18-24 in cormutus. See Gilbert, C.R., 1964, Bull. Fla. St. Mus. 8(2):95-194, and Miller, R.J., Copeia 1968 (3):640-647, for opposing opinions.

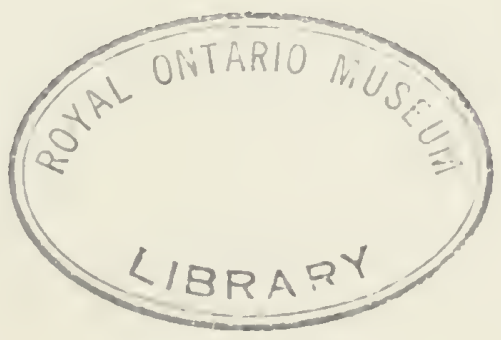


32 Snout sharp, its length more than two-thirds distance from posterior margin of eye to posterior margin of gill-cover; pigmentation on sides usually bordered below by lateral line.

$$
\text { Rosyface shiner, Notropis mbelzus }
$$

Snout blunt, its length less than two-thirds distance from posterior margin of eye to posterior margin of gill-cover; pigmentation on sides terminating above lateral line. Emerald shiner, Notropis atherinoides

33 Intestine short, with single main loop; mouth usually terminal (subterminal for $N$. b Zennius

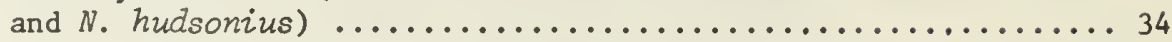

Intestine elongate, coiled on right side; mouth subterminal $\ldots \ldots \ldots \ldots \ldots \ldots \ldots \ldots \ldots \ldots \ldots \ldots \ldots \ldots \ldots \ldots \ldots \ldots \ldots$

34 Dorsal fin with black blotch on membranes between posterior rays (except in young); eye less than one-quarter length of head in adults; snout sharp or pointed.

Spotfin shiner, Notropis spilopterus

Dorsal fin without black blotch on membranes between posterior rays; eye more than onequarter length of head in adults; snout not sharp or pointed $\ldots \ldots \ldots \ldots \ldots \ldots \ldots \ldots \ldots \ldots \ldots \ldots \ldots \ldots \ldots$

35 Lateral band indistinct or absent, sometimes diffuse posteriorly; body somewhat compressed,

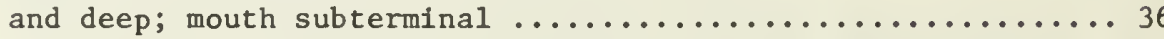

Lateral band usually distinct (less so on $N$. voluce $Z$ Zus and $N$. stramineus), often extending onto head; body slender; mouth

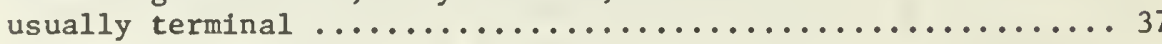


36 A large, conspicuous black spot at base of caudal fin (particularly obvious on young); scales in lateral line $36-39$; anal rays 8 . Spottail shiner, Notropis hudsonius

No black spot at caudal base; scales in lateral line 35-37; anal rays 7 .

River shiner, Notropis blennius

37 Lateral band usually dark and obvious, continued forward through eye and onto snout;

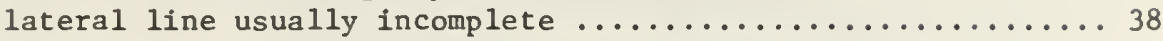

Lateral band weakly developed or dusky, not continued forward through eye; lateral line complete ................................... 41

38 Mouth very small, almost vertical; upper jaw extending only to vertical through nostril; lateral line nearly or quite complete; peritoneum black.

Pugnose shiner, Notropis anogenus

Mouth larger, upper jaw reaching beyond a vertical through nostril almost to below eye; lateral line incomplete; peritoneum silvery

39 Lateral band on chin (chin black), and on premaxillaries.

Blackchin shiner, Notropis heterodon

Lateral band on snout but not on chin (chin

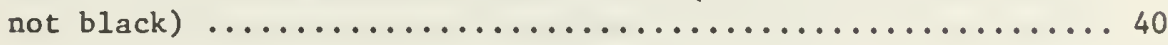

40 Anal rays typically 8; dorsal fin located behind vertical through pelvic insertion.

Blacknose shiner, Notropis heterolepis

Anal rays typically 7 ; dorsal fin inserted over or before a vertical through pelvic insertion.

Bridle shiner, Notropis bifrenatus 
41 Anal rays usually 8 (sometimes 9); black pigment about anus and base of anal fin; pigmentation extending below lateral line. Mimic shiner, Notropis volucelzus

Anal rays usually 7; little or no black pigment about anus or base of anal fin, nor below lateral line.

Sand shiner, Notropis stramineus

42 Dorsal fin rounded; scales with about 20 radil in adult; colour brassy.

Brassy minnow, Hybognathus hankinsoni

Dorsal fin somewhat falcate; scales with about 10 radil in adult; colour silvery.

Silvery minnow, Hybognathus nuchalis

\section{KEY TO THE SPECIES OF THE FAMILY CATOSTOMIDAE}

1 Dorsal fin with long base and more than 20 rays, first 4-7 rays of dorsal extended to form pointed or rounded lobe at least as high again as rest of $\mathrm{fin}$; distance from insertion of dorsal to origin of caudal less than dorsal

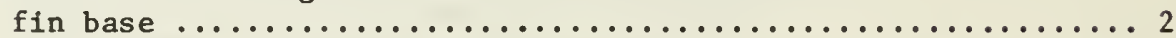

Dorsal fin with short base and fewer than 20 rays, no rounded or pointed anterior lobe, rays a unfform gradation in length; distance from insertion of dorsal to origin of caudal

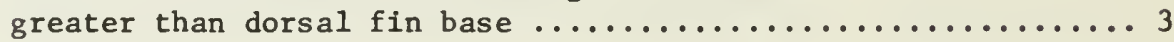

2 Dorsal fin with moderate anterior lobe, first ray about 3 times as long as shortest dorsal ray; mouth horizontal to oblique, 
subterminal but little overhung by snout, mouth larger - maxillary twice eye diameter; caudal fin with shallow fork.

Bigmouth buffalo, Ictiobus cypminellus

Dorsal fin with very high, pointed, anterior lobe, first ray at least 4 times as long as shortest ray; mouth, horizontal, inferior and markedly overhung by snout, mouth small - maxillary about equal to eye diameter; caudal with deep fork.

Quillback, Carpiodes cyprinus

3 Lateral line present; snout rounded; mouth horizontal, inferior and overhung by snout; greatest body depth less than one-third the

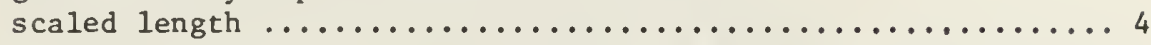

Lateral line absent; snout broadly pointed; mouth oblique and only subterminal, not noticeably overhung by snout; greatest depth one-third or greater than one-third of scaled length; dorsal fin appears large for body length; wide, horizontal, midlateral black band except in largest specimens; usually no more than $120-150 \mathrm{~mm}$ (5-6 inches) in length. Lake chubsucker, Erimyzon sucetta

4 Side of body with prominent spotted pattern, approximately 10 horizontal rows of dark spots about the size of the pupil, one on each scale.

Spotted sucker, Minytrema melanops

No such pattern of small spots $\ldots \ldots \ldots \ldots \ldots \ldots \ldots \ldots \ldots \ldots \ldots \ldots$

5 Head large and broad, depression between eyes; eyes very high and past midpoint of head; snout long and markedly turned down; 
body pattern of dark blotches and 3 wide, oblique bars; usually not over $200 \mathrm{~mm}$

( 8 inches) in length.

Northern hog sucker, Hypentelium nigmicans

Head convex or rounded on top, eyes lower, and approximately in middle of head $\ldots \ldots \ldots \ldots \ldots \ldots \ldots \ldots$

6 Scales small, more than 55 in lateral line;

swim bladder with 2 chambers; body cylin-

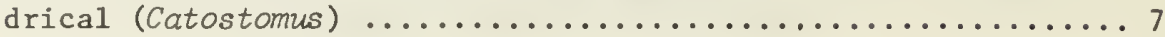

Scales larger, fewer than 50 in lateral line;

swim bladder with 3 chambers; body subcylin-

drical to laterally compressed (Moxostoma) .............. 11

7 Scales small, over 90 in lateral line ................ 8

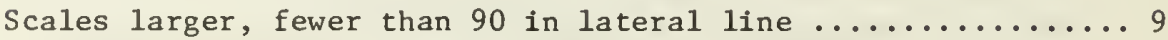

8 Lower lip not completely cleft, 3 rows of papillae cross the base; 3 or 4 rows of papillae on upper lip; cartilagenous edge of jaws obvious inside lips when mouth open; sometimes a notch at point of lateral connection of upper and lower lips; least caudal peduncle depth less than one-half length of dorsal base; membranous connection between base of pelvic fins and body; not over $375 \mathrm{~mm}$ (15 inches) in length. Bridgelip sucker, Catostomus columbianus

Lower lip completely cleft, no rows of papi1lae cross base, at most one row of small papillae on floor of cleft; only 2 rows of papillae on upper 1ip; cartilagenous edge of jaw not conspicuous without pulling lips back; never a notch at point of lateral connection of upper and lower lips; least caudal peduncle depth more than one-half length of dorsal base; no membranous stays between pelvic fins and body. Longnose sucker, Catostomus catostomus 
9 Lower lip incompletely cleft, 3 or 4 rows of papillae crossing base; cartilagenous edge of jaws visible inside lips when mouth open; pronounced notch at point of lateral connection of upper and lower lips; anterior margin of upper lip not pappilate, no upper lip papillae visible from front; more than 15 oblique rows of scales from lateral line to origin of dorsal; never more than $200 \mathrm{~mm}$ ( 8 inches) in length.

Mountain sucker, Catostomus platymynchus

Lower lip completely cleft, no rows of papillae crossing base; cartilagenous edge of jaws not conspicuous; no notch at point of lateral connection of lips, papillae of upper lip visible from front; fewer than 15 oblique rows of scales from lateral line to origin of dorsal; size at least to $610 \mathrm{~mm}$ (24 inches)

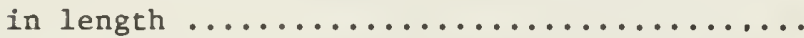

10 Lower lip much wider than its height; oblique rows of scales from lateral line to dorsal origin 8-10; dorsal fin rays $10-12$; least caudal peduncle depth more than one-half length of dorsal $\mathrm{f}$ in base; no membranous connection between pelvic fins and body.

White sucker, Catostomus commersoni

Lower lip almost as high as wide; oblique rows of scales from lateral line to dorsal origin 11-14; dorsal fin rays usually 13-15 (rarely 12 or 16); least caudal peduncle depth less than one-half the dorsal fin base; membranous connection between pelvic fins and body.

Largescale sucker, Catostomus macrocheilus

11 Scales around the caudal peduncle equal $16 \ldots \ldots \ldots \ldots \ldots \ldots$

Scales around the caudal peduncle equal 12 or

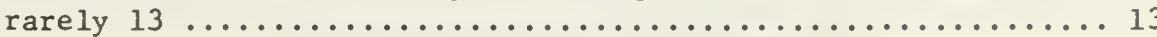


12 Maximum depth into scaled length of body less than $3 \frac{1}{2}$ times; tip of snout to centre of pupil less than centre of pupil to posterior edge of operculum; plicae of lips crossed by transverse lines; lower lips meet mid-ventral at an acute angle.

Copper redhorse, Moxostoma hubbsi

Maximum depth into scaled length of body about 4 times or over; tip of snout to centre of pupil greater than centre of pupil to posterior edge of operculum; no transverse lines crossing plicae; lower lips meet at an obtuse angle.

Greater redhorse, Moxostoma valenciennesi

13 Maximum depth into scaled length 3.5 times or less; plicae of lips with distinct transverse lines, lower lip thin.

Silver redhorse, Moxostoma anisumum

Maximum depth into scaled length about 4 times or more; no transverse lines crossing plicae of lips, lower lip thicker $\ldots \ldots \ldots \ldots \ldots \ldots \ldots \ldots$

14 Origin of pelvic fins anterior to the midpoint of the base of the dorsal fin; lower pharyngeal arch heavy and triangular; teeth increasing in size toward bottom, subcylindrical and reduced in number.

River redhorse, Moxostoma carinatron

Origin of pelvic fins opposite the mid-point of the base of the dorsal fin; lower pharyngeal less heavy not triangular; teeth compressed, comb-like, and numerous $\ldots \ldots \ldots \ldots \ldots \ldots \ldots \ldots \ldots \ldots \ldots$

15 Eye diameter equal to about one-half the maximum width of the lips; nostrils above the tip of the maxillary.

Black redhorse, Moxostoma duquesnei

Eye diameter equal to two-thirds or more of the maximum width of the lips; nostrils be-

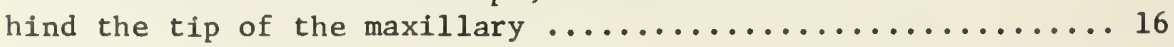


16 Posterior edge of lower lips nearly a straight line; mouth sma11, lips not reaching maximum width of snout; mouth overhung by snout; head roundly pointed, contained 4.3-5. 4 times in standard length.

Northern redhorse, Moxostoma macrolepidotum

Posterior edge of lower lips a definite obtuse angle; head more flattened at front; mouth larger, lips reaching maximum width of snout; mouth little overhung by snout.

Golden redhorse, Moxostoma erythmumm

\section{KEY TO THE SPECIES OF THE FAMILY ICTALURIDAE}

1 Adipose fin short, fleshy, free at posterior end, obviously well separated from the caudal fin; tail round, squared, or forked; can be

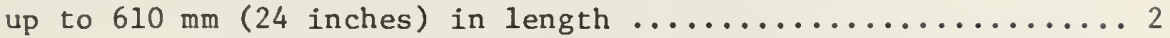

Adipose fin long, low, a simple, ridge-like extension of the caudal fin, with or without a notch marking point of connection; tail round, or squared; never over $305 \mathrm{~mm}$ (12

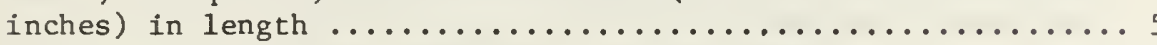

2 Caudal fin deeply forked; obvious bony ridge connecting sku11 and origin of dorsal; barbels at corners of mouth more than 3 times as long as those near nostrils.

Channel catfish, Ictalums punctatus

Caudal fin round, square, or slightly indented, never deeply forked; area between head and origin of dorsal compressable, no bony ridge; barbels at corners of mouth about twice as long as those near nostrils .................. 
3 Upper barbels gr: to yellow, lower barbels yellow to white; depressed anal fin overlaps anterior rays of caudal fin; distance from isthmus notch to lower $j$ aw notch much less than distance from lower jaw notch to tip of lower jaw.

Yellow bullhead, Ictalurus natalis

Upper and lower barbels dark brown to black; anal fin does not reach anterior rays of caudal fin; distance between isthmus and lower $j$ aw notches close to distance from lower jaw

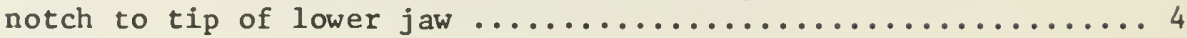

4 Barbs on trailing edge of pectoral spines strong even near tip, and catch fingernail when moved toward tip; anal rays usually $21-$ 24 ; dorsal ray membranes not noticeably darkened.

Brown bullhead, Ictalumus nebulosus

Barbs on trailing edge of pectoral spines weak or absent, especially near tip, if present near base, barbs usually catch fingernail only when moved toward base; anal rays usually 17-21; dorsal ray membranes usual.'y noticeably darkened.

Black bullhead, Ictalurus melas

5 Dorsal surface more or less flat to origin of adipose fin, greatest depth, at origin of dorsal, into body length to base of caudal rays over 6 times; strongly countershaded, dark above, yellow to white below, small white to yellow spot at dorsal insertion; premaxillary tooth patch with lateral extensions; can be to $305 \mathrm{~mm}$ (12 inches) in length.

Stonecat, Noturus flavus

Dorsal surface rises to obvious apex at dorsal origin, greatest depth into body length 
to base of caudal rays about 4 times; generally dark, or pale with dark saddles and bars; premaxillary tooth patch without lateral extensions; never over $152 \mathrm{~mm}$

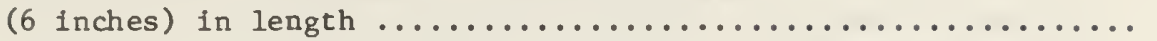

6 Body pale, conspicuously marked with dark saddles and bars; ventral surface white to yellowish; caudal fin outlined in black and white; very strong barbs on pectoral spines; dorsal spine at least three-quarters maximum height of dorsal fin. Brindled madtom, Notums miumus

Body generally dark, ventral surface dusky, often 3 noticeable dark horizontal lines behind dorsal fin; myotomes of ten obvious; caudal fin dusky; no barbs on pectoral spines; dorsal spine not more than one-half maximum height of dorsal fin.

Tadpole madtom, Notumus gyminus

KEY TO THE SPECIES OF THE FAMILY CYPRINODONTIDAE

1 Gill rakers usually 5, widely spaced and obvious; branchiostegal rays 6,6 , never 5,5 ; distance from origin of dorsal to end of vertebral column when stepped forward from dorsal fin origin, reaches a point about middle of eye.

Banded killifish, Fundulus diaphanus

Gill rakers usually 9 or more, crowded and not obvious; branchiostegal rays 5,5, rarely 6,6 ; distance from origin of dorsal fin to end of vertebral column when stepped forward from dorsal fin origin, reaches to posterior half of operculum.

Mummichog, Fundulus heteroclitus 
1 Two dorsal fins, base of first short, length of base of second 6 or more times that of the first; one anal fin.

$$
\text { Burbot, Lota Zota }
$$

Two dorsal fins, bases of near equal length; two anal fins.

Tomcod, Microgadus tomcod

KEY TO THE SPECIES OF THE FAMILY GASTEROSTEIDAE

1 Dorsal spines usually $9(7-12)$, short and inclined alternately to left and right; gill membranes united but entirely free from isthmus; a median ventral plate present; no bony plates on sides.

Ninespine stickleback, Pungitius prongitius

Dorsal spines 3-6; gill membranes united to isthmus; lateral bony plates present or ab-

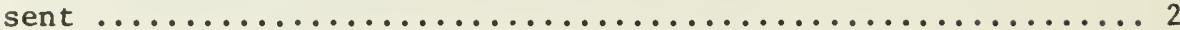

2 Dorsal spines 4, 5 or 6; spines may be long or short; no bony plates on sides; belly posterior to pelvic bases not plated

Dorsal spines 3 (rarely 2 or 4), usually with vertical bony plates along sides; a long bony plate extending posteriorly

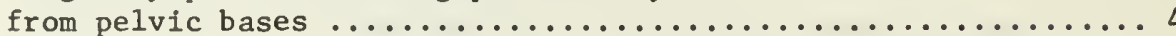

3 Dorsal spines 4, 5 or 6, short; pelvic spines also short; length of all spines 
less than eye diameter.

Brook stickleback, Culaea inconstans

Dorsal spines 4 (rarely 5), long, inclined alternately to left and right; length of first and second dorsal spines and pelvic spines distinctly greater than eye diameter.

Fourspine stickleback, Apeltes quadracus

4 Pelvic fin of one spine and one soft ray, spine with one pointed cusp at base; caudal peduncle with a keel; body without round black spots; colour in life, green, blue or silvery.

Threespine stickleback, Gasterosteus aculeatus

Pelvic fin of one spine and 2 soft rays, spine with 2 well-developed pointed cusps at base; caudal peduncle keelless; many round black spots along sides; colour in life, lemon-yellow.

Blackspot stickleback, Gasterosteus wheat Zandi

KEY TO THE SPECIES OF THE FAMILY SERRANIDAE

1 Dorsal fins slightly joined at base by membrane; sort anal rays 9 or 10 ; anal spines stout, not graduated in length, second and third spines subequal; no teeth on base of tongue; no lateral stripes.

White perch, Roccus americanus

Dorsal fins entirely separated at base; soft anal rays 10 to 13 ; anal spines graduated in length; fine teeth at base of

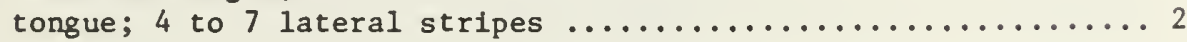


2 Soft anal rays 12 or 13 ; anal spines slender, the longest spine equal to or greater than one-half height of fin.

White bass, Roccus chrysops

Soft anal rays 10 or 11 ; anal spines more slender, longest spine less than one-half height of fin.

Striped bass, Roccus saxatilis

KEY TO THE SPECIES OF THE FAMILY CENTRARCHIDAE

1 Dorsal spines $10-12$; branchiostegal rays 6 (rarely 5); base of anal fin into base of

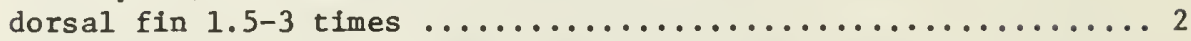

Dorsal spines $6-8$; branchiostegal rays 7 ; base of anal fin equal to, or slightly longer than base of dorsal (crappies, Pomoxis) .................

2 Anal spines 6; spines arise in a scaled groove; body with 7-9 horizontal rows of black spots below lateral line; base of anal about 1.5 times into base of dorsal. Rock bass, Ambloplites mpestris

Anal spines 3, not in groove, no horizontal rows of spots below lateral line, base of anal into base of dorsal $2.1-3.3$ times $\ldots \ldots \ldots \ldots \ldots \ldots \ldots . \ldots$

3 Lateral line scales more than 55; greatest depth into standard length 3-3.3 times

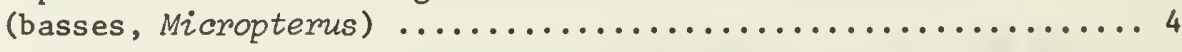

Lateral line scales fewer than 50 ; greatest depth into standard length $2-2.5$

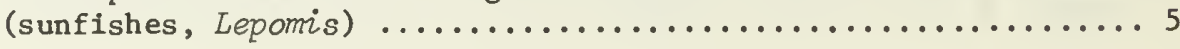


4 Upper jaw extends at least to mid-pupil but not beyond eye; connection between dorsal fins higher, shortest spine more than onehalf the longest; $68-81$ scales in lateral line; pelvic fins joined by membrane, nıembrane connecting fins to body hidden; young with conspicuous orange and black bands on caudal fin.

Smallmouth bass, Microptems dolomieui

Upper jaw extends beyond eye; connection between dorsal fins lower, shortest spine less than one-half the longest; 58-69 scales in lateral line; pelvic fins not joined by membrane, membrane connecting fins to body obvious; young without colourful pigment on caudal fin but with prominent lateral band. Largemouth bass, Micropterus salmoides

5 Opercular flap in life with black centre and yellow, orange, or red spots or band around margin (in preserved specimens the once coloured areas are white or colourless) $\ldots \ldots \ldots \ldots \ldots \ldots \ldots \ldots$

Opercular flap in life all black, not marked or edged by yellow, orange, or red in life (not edged with white or colourless in preserved specimens) $\ldots \ldots \ldots \ldots \ldots \ldots \ldots \ldots \ldots \ldots \ldots \ldots \ldots \ldots$

6 Pectoral fins longer, 3 times in standard length, pointed at leading edge; gill rakers very short and knobbed; opercular flap short, black in centre, edged with white or yellow, with prominent well defined red spot at posterior edge.

Pumpkinseed, Lepomis gibbosus

Pectoral fins shorter, 4 times in standard length and rounded; gill rakers short but not knobbed; opercular flap longer, black in centre, edged with yellow, orange, or red, no prominent precise red spot $\ldots \ldots \ldots \ldots \ldots \ldots \ldots \ldots \ldots \ldots$ 
7 Black area of opercular flap usually as deep as long, bony edge of flap entire, not crenate; gill rakers long and slender; pectoral fin long and pointed; base of anal fin into base of dorsal fins 2.0-2.3 times; ventral edge of preopercle finely serrate; black spot at posterior base of second dorsal fin. Bluegi11, Lepomis macrochimus

Black area of opercular flap usually longer than deep; bony edge of flap crenate; gill rakers short and stout; pectoral fin short and rounded; base of anal into base of dorsals 2.3-2.6 times; preopercle not serrate; no black spot at posterfor base of second dorsal fin.

Redbreast sunfish, Lepomis curitus

8 Opercular flap as deep as long, black area edged with red and/or yellow, most prominently on bottom and end; bony edge entire, not crenate; scales smaller, 44 or more in lateral line, 8-10 diagonal rows of scales between lateral line and dorsal origin.

Green sunfish, Lepomis cyanellus

Opercular flap long, narrow, turned up, black area completely edged with red and/or yellow; bony edge crenate; scales larger, 39 or more in lateral line, 4-6 diagonal rows between lateral line and dorsal origin. Longear sunfish, Lepomis megalotis

9 Dorsal spines 6 ; base of anal fin longer than base of dorsal fins; eye diameter 6 times in head, 2 times in snout; body pale with 6-8 vertical bars (prominent in life). White crappie, Pomoxis annularis

Dorsal spines 7 or 8 ; base of anal fin equal to base of dorsal fin; eye diameter 4-5 times in head, less than 2 times in snout; body darkly and irregularly blotched with black. Black crappie, Pomoxis nigromaculatus 
1 Mouth large, maxillary extending to midpoint of eye or beyond; lower borders of preopercle obviously serrate; branchiostegals 7 or 8 ; mod-

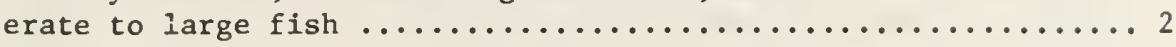

Mouth small, maxillary usually not extending beyond anterior margin of eye; lower borders of preopercle smooth, not serrate; branchiostegals 6 (rarely 5); small bottom dwellers, never over $152 \mathrm{~mm}$ ( 6 inches) in length. (dar-

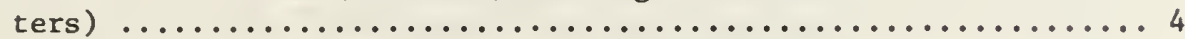

2 Anal fin with 2 spines and 6-8 soft rays; teeth in lower $\mathrm{j}$ aw all about equal height, no canines on tip; space between pelvic fins less than width of base of one fin; body deeper and laterally compressed, with 6-8 wide dark vertical bars.

Yellow perch, Perca flavescens

Anal fin with 2 spines and 12 or 13 soft rays; canine teeth present, usually two on tip of lower jaw; space between pelvic fins equal to base of one fin; body shallower

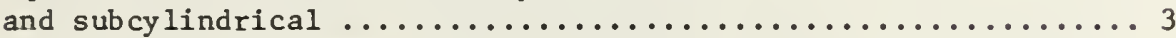

3 Rays of second dorsal fin usually 18-22; membrane of first dorsal dusky without definite spots, a large black blotch at posterior base of spinous dorsal in adults; lower lobe of caudal fin with white tip; in adults, cheek scales small, hard to see, cheek and operculum naked at $152 \mathrm{~mm}$ ( 6 inches) 
in length; 3 pyloric caecae each about as long as stomach; 5-7 dark saddles on back.

Walleye, Stizostedion vitreron*

Rays of second dorsal fin usually 17-20; membrane of first dorsal clear with definite spots, in young, pigment confined to upper edge, no large blotch at posterior base; lower lobe of caudal fin without white tip; in adults cheek scales more apparent, cheek naked but scales on operculum obvious at $152 \mathrm{~mm}$ (6 inches) in length; usually 5 (3-9) pyloric caecae, each shorter than stomach; back with 3 or 4 saddles which become patches below fins and on peduncle.

Sauger, Stizostedion canadense

4 Anal fin large, equal to or larger than soft dorsal fin; pelvic fins well separated; caudal fin usually slightly forked; lateral line usually complete; space between pelvic bases and along belly either naked or with enlarged ctenoid scales, females sometimes with only one enlarged scale between pelvic fins; body usually

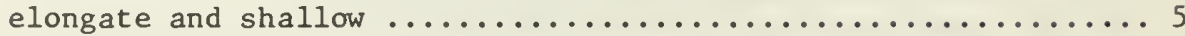

Anal fin smaller than soft dorsal fin; distance between pelvic fins variable, from width of pelvic base to one-half pelvic base; caudal fin slightly forked, square or rounded; lateral line complete or incomplete; space between pelvic fins and along belly either naked or with scales, but scales never enlarged, body usually

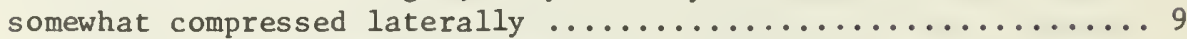

* No attempt is made to separate here the subspecies Stizostedion vitreron glaucum, the blue pike. The species occurred only in Lakes Erie and Ontario and apparently has been extirpated. Specimens of a dull grey form reported from various inland lakes have proven to be colour mutants of the walleye, $S$. $v$. vitreim. 
5 Flesh pellucid in life; anal fin with a single thin spine; dorsal fins widely separated; body extremely elongate and partially naked, with scales confined to midline of sides; a series of 10-12 small, rounded, green spots along midline of sides.

Sand darter, Ammocmpta pelzucida

Flesh opague; anal fin with 2 spines; dorsal fins not widely separated; body usually scaled

6 Premaxillaries protractile, clearly separated from snout by a deep groove; a series of small brown oblong or round blotches along sides, frequently joined together by a thin line.

Channel darter, Percina copelandi

Premaxillaires not protractile (a shallow groove may be evident in $P$. shumardi) $\ldots \ldots \ldots \ldots \ldots \ldots \ldots \ldots$

7 Snout prolonged to from a conical protuberance, projecting beyond upper jaw;

lateral line scales 78-103; body with 1416 dark vertical bars, alternate bars being expanded and drop-like at lower ends; a distinct black spot at caudal base.

Logperch, Percina caprodes

Snout not prolonged, not projecting beyond upper jaw; lateral line scales fewer than 78; body with lateral blotches, with or without black spot at caudal base ..................... 8

8 Cheeks scaleless; midline of belly scaleless but with a bridge of scales before anus; a prominent suborbital bar; anal fin 
usually large, the rays long, reaching almost to base of caudal fin; sides with 9 or 10 blotches or bars.

River darter, Percina shumardi

Cheeks scaled; midline of belly scaled; suborbital bar present; anal fin not unusually large, not reaching to caudal base; sides with a series of black, oblong, confluent blotches and continuous with a black band that extends across gill cover and around snout.

Blackside darter, Etheostoma maculation

9 Premaxillaries protractile; one thin anal spine; body usually with X-, M-, or W-shaped markings on sides.

Johnny darter, Etheostoma nigmo*

Premaxillaries not protractile, usually

bound to snout by fleshy bridge (the

frenum) or fused to preorbitals at sides

( $E$. blennioides); two anal spines, the

first usually stout and stiff ...................... 10

10 Gill membranes not obviously joined but

meeting in a $\mathrm{V}$ over isthmus .......................... 11

Gill membranes broadly joined by a sheet of tissue covering isthmus but free from

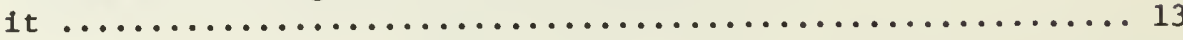

* Throughout its North American range Etheostoma (Boleosoma) nigrum was considered for many years to be represented by three subspecies, all of which occurred in Canadian waters, $E$. n. olmstedi from Maritime provinces to eastern Lake Ontario drainages, $E$. $n$. eulepis in Great Lakes basin and $E$. n. nigmm from Saskatchewan and Hudson Bay to western Quebec. However, Cole (1967) elevated olmstedi to full species status but as yet the occurrence of this species $E$. olmstedi Storer in Canadian waters is not clearly defined. 
11 Cheeks scaled (scales sometimes covered lightly with tissue); dorsal soft rays usually 10 or 11; lateral line ending under spinous dorsal fin; 10-12 dark vertical bars on sides, not extending downward to ventral surface; caudal fin distinctly speckled; males colourful in life with blue or green patches between darker bars on sides and blue and red on spinous dorsal fin. Iowa darter, Etheostoma exile

Cheeks naked; dorsal rays usually $12-13$, or $8-9$; lateral line variously incomplete or absent $\ldots \ldots \ldots \ldots \ldots \ldots \ldots$

12 Dorsal rays 12 or 13 ; dorsal spines 9 or 10 ; lateral line usually incomplete; 6 dark, vertical bands on body from anus to tail, meeting (or nearly so), on ventral surface; males colourful in life with green, blue, and orange colouration on head, sides, dorsal and anal fins. Rainbow darter, Etheostoma caerulerm

Dorsal rays 8 or 9 ; dorsal spines 7 ; latera1 line completely absent or with up to 7 pored scales; sides with 7 or 8 squarish, dark patches on sides; a distinct suborbital bar; caudal fin distinctly barred or speckled.

Least darter, Etheostoma microperca

13 Dorsal spines 6-8, short, length equal to or shorter than eye diameter, those of males often with fleshy tips; body slender, elongate; head distinctly pointed, mouth terminal; colour in life brownish, with 10-12 short, vertical bars. Fantail darter, Etheostoma flabellare

Dorsal spines 13, not short, length obviously greater than eye diameter and never with fleshy tips; body robust; snout distinctly rounded, overhanging the small mouth; body greenish in life with $\mathrm{V}$-shaped marks that extend below the midline.

Greenside darter, Etheostoma blennioides 
1 Gill membranes free from isthmus; second preopercular spine directed backwards, conspicuous.

Deepwater sculpin, Myoxocephalus quadricomis

Gill membranes attached to isthmus; second preopercular spine skin covered, and directed down-

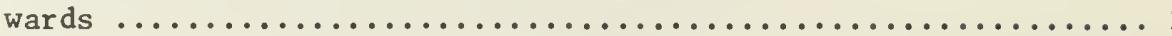

2 Lateral line complete to base of caudal without deflection; upper preopercular spine usually longer than two-thirds eye diameter and curved inwardly; mandibular pores large, one on midline of tip of chin.

Spoonhead sculpin, Cottus ricei

Lateral line incomplete, or if complete deflected downwards on caudal peduncle; upper preopercular spine equal to one-half eye diameter and not cur-

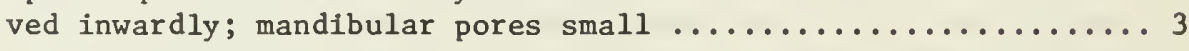

3 Two pores on tip of chin; lateral line complete or incomplete; first 2 dorsal spines not noticeably close together (associated with separate basals); caudal vertebrae $20-24 \ldots \ldots \ldots \ldots \ldots \ldots \ldots \ldots \ldots \ldots$

One pore on tip of chin; lateral line complete; first 2 dorsal spines noticeably close together (associated with single basal); caudal verte-

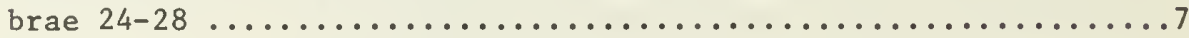

4 Lateral line complete; palatine tooth patch long, and in contact with vomerine tooth patch; head length 3 times or less in standard length; prickles on body usually extending onto sides and back; base of prickle serrate; usually 2 narrow, forward- 
slanting bars under second dorsal fin; underside of head mottled with large and small speckles.

\section{Torrent sculpin, Cottus rhotheus}

Lateral line complete or incomplete; palatine tooth patch absent or short, not in contact with vomerine tooth patch; head length usually 3 times or more in standard length; prickles restricted to a small area behind pelvic fin; base of prickle not serrate; either 3 dark bars or none under second dorsal fin; underside of head uniformly speckled .....................

5 Palatine teeth absent; anal fin rays usually 10-12; pelvic fin rays 3 or 4, when present the fourth ray usually less than two-thirds length of longest pelvic ray; last 2 dorsal and anal rays often separated, arising from separate basals.

$$
\text { Slimy sculpin, Cottus cognatus }
$$

Palatine teeth present; anal fin rays usually 12-14; pelvic fin rays 4, the fourth about three-quarters length of the longest ray; last 2 dorsal and anal rays close together,

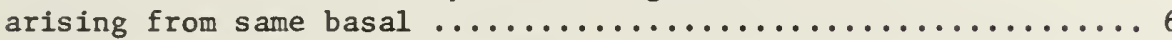

6 Head length usually 2.9-3.2 in standard length; pectoral fin rays usually $14-16$; lateral line incomplete and usually of $28-36$ pores; preopercular spines 3.

Mottled sculpin, Cottus bairdi

Head length usually 3.2-3.9 in standard length; pectoral fin rays usually 13 or 14 ; lateral line incomplete and usually of 22-33 pores; preopercular spines 2 .

Shorthead sculpin, Cottus confusus 
7 Anal fin rays 15-19; pectoral fin rays 1518; palatine teeth present; dark, oval spot on upper posterior portion of first dorsal fin.

Prickly sculpin, Cottus asper

Anal fin rays 12-16; pectoral fin rays 1316; palatine teeth absent; dark, oval spot absent on first dorsal fin.

Coastrange sculpin, Cottus aleuticus 
The species below are fishes which have been recorded from fresh waterin Canada but either so rarely or on such tenuous circumstances as to make doubtful their real establishment in fresh water.

f. Squalidae - dogfish sharks; Squalus acanthias Linnaeus - spiny dogfish; B.C., (McAllister, 1959a).

f. Clupeidae - herrings; Clupea harengus pallasi Valenciennes Pacific herring; B.C., (McAllister, 1959a).

f. Salmonidae - salmons, trouts, whitefishes, and grayling; Salmo aguabonita Jordan - golden trout; introduction in Alberta of unknown success. Salmo salar Linnaeus - Atlantic salmon; recently introduced in 1akes in National Parks in Alberta.

f. Cyprinodontidae - killifishes; Lebistes reticulatus (Peters) guppy; Alta. MolZienesia Zatipinna Lesueur - sailfin molly; Alta. Xiphophoms hellem Heckel - swordtail; Alta. Aquarium specimens introduced into hot springs near Banff and surviving.

f. Cichlidae - cichlids; Cichlosoma nigrofasciatum (Günther) - zebra cichlid; Alta. Aquarium specimens introduced into hot springs near Banff and surviving.

f. Embiotocidae - surfperches; Cymatogaster aggregata Gibbons shiner perch; B.C., (McAllister, 1959a).

f. Cottidae - sculpins; Clinocottus acuticeps (Gilbert) - sharpnose sculpin; B.C., (McAllister, 1959a). Leptocottus armatus Girard Pacific staghom sculpin; B.C., (McAllister, 1959a). Myoxocephalus quadricomis (Linnaeus) - fourhorn sculpin; Man.

f. Cyclopteridae - lumpfishes and snailfishes; Cyclopterus Zumpus Linnaeus - lumpfish; Ont., (Ryder et al, 1964).

f. Ammodytidae - sand 1ances; Ammodytes comericanus DeKay - American sand 1ance; Nfld., (Scott and Crossman, 1964).

f. Bothidae - lefteye flounders; ScophthaZmus aquosus (Mitchil1) windowpane; Nfld., (Scott and Crossman, 1964). 
f. Pleuronectidae - righteye flounders; Liopsetta putnomi (Gill) smooth flounder; N.B., Que., Vladykov (pers. comm.) stated that this flounder had been taken in the St. Lawrence River, 30 miles from the sea. There are specimens in the ROM from freshwater in the Waweig River, N.B. MacKenzie (1959) reported them as taken "just above Newcastle" on the Miramichi River where salinities are as low as $0.1 \%$. Platichthys stellatus (Pallas) - starry flounder; B.C. The adults of this species have long been known to enter freshwater. The adults as we11 regularly occur in at least marginal freshwater (see Carl et al, 1959; McAllister, 1959a). Pseudopleuronectes comericonus (Walbaum) winter flounder; Nf1d., (Scott and Crossman, 1964). 
NUMBER OF SPECIES BY GEOGRAPHIC AREAS IN A TOTAL FAUNA OF 183 SPECIES

Number of Species 1969

Insular Newfoundland 20

Labrador (Nfld.) 21

Nova Scotia 34

Prince Edward Island 19

New Brunswick 48

Quebec 106

Ontario 136

Manitoba 76

Saskatchewan 59

Alberta 53

British Columbia 72

Northwest Territories 41

Yukon Territory 32

Alaska 39

NUMBER OF SPECIES IN MAJOR WATERSHED BASINS

Atlantic 146

Hudson Bay 94

Arctic 56

Pacific 70

Gulf of Mexico 27 


\section{ATLANTIC WATERSHED BASIN}

\section{6 species}

Lompetra Zamottei

Ichthyomyzon fossor

Ich thyomyzon unicuspis

Petromyzon marinus

Acipenser brevirostrom

Acipenser fulvescens

Acipenser oxyrhynchus

Lepisosteus oculatus

Lepisosteus osseus

Amia calva

Alosa aestivalus

Alosa pseudoharengus

Alosa sapidissima

Dorosoma cepedianum

Coregonus alpenae

Coregonus artedii

Coregonus clupeaformis

Coregonus hoyi

Coregonus johonnae

Coregonus kiyi

Coregonus nigripinnis

Coregonus nipigon

Coregonus reighardi

Coregonus zenithicus

Coregonus sp.

Oncorhynchus gorbuscha*

Oncorhynchus kisutch*?

oncorhynchus nerka*
Oncorhynchus tshouytscha*

Prosopium coulteri

Prosopizon cylindraceion

Salmo clarki *

Salmo gairdneri*

Salmo salar

Salmo trutta*

Salvelinus alpinus

Salvelinus fontinalis

Salvelinus namaycush

Thymallus areticus*?

Osmerus epertanus

Hiodon alosoides

Hiodon tergisus

Dallia pectoralis*?

umbra limi

Esox americanus

Esox Zucius

Esox masquinongy

Esox niger

Carassius auratus*

Chrosomus eos

Chrosomus neogaeus

clinostomus elongatus

Conesius plrombeus

Cyprinus carpio*

Exoglossum maxillingua

Hybognathus hankinsoni

Hybognathus nuchalis 


\section{ATLANTIC WATERSHED BASIN (cont.)}

Hybopsis storemiana

Hybopsis $x$-pronctata

Nocomis biguttata

Nocomis micropogon

Notemigonus crysoleucas

Notropis conogenus

Notropis atherinoides

Notropis bifrenatus

Notropis chrysocephalus

Notropis cornutus

Notropis heterodon

Notropis heterolepis

Notropis hudsonius

Notropis mibellus

Notropis spilopterus

Notropis stromineus

Notropis umbratilis

Notropis volucellus

opsopoeodus emiliae

Pimephales notatus

Pimephales promelas

Rhinichthys atratulus

Rhinichthys cataractae

Semotilus atromaculatus

Semotilus corporalis

Semotilus margarita

Carpiodes cyprinus

Catostomus catostomus

Catostomus commersoni
Erimyzon sucetta

Hypentelizon nigricans

Ictiobus cyprinellus

Minytrema melanops

Moxos toma anisurrom

Moxos toma carinatrom

Moxos toma erythrumom

Moxos toma hubbsi

Moxostoma macrolepidotum

Moxostoma valenciennesi

Ictalumus melas

Ictalurus natalis

Ictalurus nebulosus

Ictalurus punctatus

Noturus flavus

Notums gyminus

Noturus miurus

Anguilza rostrata

Fundulus diaphanus

Fundulus heteroclitus

Lota Zota

Microgadus tomcod

Labidesthes sicculus

Apeltes quadracus

Culaea inconstans

Gasterosteus aculeatus

Gasterosteus wheatlandi

Prongitius pungitius

Percopsis omiscomaycus

Roccus americanus 


\section{ATLANTIC WATERSHED BASIN (cont.)}

Roccus chrysops

Roccus saxatizis

Ambloplites mupestris

Lepomis auritus

Leporis cyonellus

Lepomis gibbosus

Lepomis macrochirus

Lepomis megalotis

Micropterus dolomieui

Micropterus salmoides

Pomoxis annularis

Pomoxis nigromaculatus

Ammocrypta pellucida

Etheostoma blennioides

Etheostoma caemuleum

Etheostoma exile
Etheostoma flabellare

Etheostoma microperca

Etheostoma nigmum

Perca flavescens

Percina caprodes

Percina copelandi

Percina maculata

Stizostedion canadense

Stizostedion vitreion

Aplodinotus grunniens

Cottus bairdi

Cottus cognatus

Cottus ricei

Myoxocephalus quadricomis

\section{HUDSON BAY WATERSHED BASIN}

94 species

Ichthyomyzon castoneus

Ichthyomyzon unicuspis

Acipenser fulvescens

Coregonus artedii

Coregonus clupeaformis

Coregonus hoyi?

Coregonus nigripinnis

Coregonus nipigon

Coregonus zenithicus

oncorhynchus gorbuscha*?
Oncorhynchus keta*?

Oncorhynchus tshowytscha*?

Prosopizm cylindraceum

Prosopizon williamsoni

Salmo clarki

Salmo gairdneri

Salmo salar

Salmo trutta*

Salvelinus alpinus

Salvelinus fontinalis 


\section{HUDSON BAY WATERSHED BASIN (cont.)}

Salvelinus malma

salvelinus nomaycush

Thymallus arcticus

Hiodon alosoides

Hiodon tergisus

Umbra Zimi

Esox Zucius

Esox masquinongy

Carassius auratus*

Chrosomus eos

Chrosomus neogaeus

Couesius plumbeus

Cyprinus carpio*

Bybognathus hankinsoni

Hybognathus nuchalis

Nocomis biguttata

Nocomis storemiana

Notemigonus crysoleucas

Notropis atherinoides

Notropis blennius

Notropis cormutus

Notropis heterolepis

Notropis hudsonius

Notropis mbellus

Notropis stromineus

Notropis volucelzus

Pimephales notatus

Pimephales promelas

Platygobio gracilis

Rhinichthys atratulus

Rhinichthys cataractae
Semotizus atromaculatus

Semotizus corporalis

Semotizus margarita

Carpiodes cyprinus

Catostomus catostomus

Catostomus commersoni

Catostomus platyrhynchus

Ictiobus cyprinelzus

Moxostoma anisumom

Moxostoma macrolepidotion

Ictalumus melas

Ictalumus nebulosus

Ictalumus punctatus

Notumus flavus

Noturus gyminus

Fundulus diaphanus

Gombusia affinis

Lota Zota

Culaea inconstans

Gasterosteus aculeatus

Pungitius pungitius

Percopsis omiscomaycus

Ambloplites mpestris

Lepomis cyonellus

Lepomis gibbosus

Lepomis macrochims

Lepomis megalotis

Microptems dolomieui

Microptems salmoides

Pomoxis nigromaculatus

Etheostoma exile

Etheostoma nigmom 


\section{HUDSON BAY WATERSHED BASIN (cont.)}

Perca flavescens

Percina caprodes

Percina maculata

Percina shromardi

Stizostedion canadense
Stizostedion vitrewn

Aplodinotus gmoniens

Cottus bairdi

Cottus cognatus

Cottus ricei

Myoxocephalus quadricomis

\section{ARCTIC WATERSHED BASIN}

\section{6 species}

Lampetra japonica

Coregonus artedii

Coregonus autromalis

Coregonus clupeaformis

Coregonus Zaurettae

Coregonus nasus

Coregonus nelsoni

Coregonus nigripinnis

Coregonus sardinelza

Coregonus zenithicus

oncorhynchus gorbuscha

Oncorhynchus keta

oncorhynchus nerka

Oncorhynchus tshowytscha

Prosopizon coulteri

Prosopizm cylindraceim

Prosopizm williamsoni

Salmo gairdneri

Salmo trutta*

Salvelinus alpinus

Salvelinus fontinalis*
Salvelinus malma

Salvelinus namaycush

Stenodus leucichthys

Thymallus arcticus

Hypomesus olidus

Osmerus epertanus

Hiodon alosoides

Daliza pectoralis

Esox Zucius

Chrosomus eos

Chrosomus neogaeus

Couesius plumbeus

Hybognathus hankinsoni

Mylocheilus caurinus

Notropis atherinoides

Notropis hudsonius

Pimephales promelas

Platygobio gracilis

Ptychocheilus oregonensis

Rhinichthys cataractae

Richardsonius balteatus 


\section{ARCTIC WATERSHED BASIN (cont.)}

Semotilus margarita

Lota Zota

Catostomus catostomus

Catostomus commersoni

Catostomus macrocheilus

Percopsis omiscomaycus

Etheostoma exile

Perca flavescens
Stizostedion vitrewn

Cottus asper

Cottus cognatus

Cottus ricei

Myoxocephalus quadricomis

Culaea inconstans

Pungitius pungitius

\section{PACIFIC WATERSHED BASIN (+ BERING SEA)}

\section{0 species}

Lampetra japonica

Entosphenus tridentatus

Lompetra ayresi

Lampetra michardsoni

Acipenser medirostris

Acipenser transmontanus

Alosa sapidissima*

Coregonus autromalis

Coregonus clupeaformis

Coregonus pidschian

Coregonus nasus

Coregonus nelsoni

Coregonus sardinella

oncorhynchus gorbuscha

Oncorhynchus keta

Oncorhynchus kisutch

Oncorhynchus nerka

Oncorhynchus tshowytscha

Prosopizon coulteri
Prosopium cylindraceum

Prosopium williconsoni

Salmo clarki

Salmo gairdnemi

Salmo trutta*

Salvelinus fontinalis*

Salvelinus malma

Salvelinus namaycush

Stenodus leucichthys

Thymallus arcticus

Hypomesus olidus

Osmerus eperlanus

Spirinchus dilatus

Thaleichthys pacificus

Dallia pectoralis

Esox lucius

Acrocheilus alutaceus

Corassius auratus*

Couesius prombeus 


\section{PACIFIC WATERSHED BASIN (+ BERING SEA) (cont.)}

Cyprinus carpio*

Hybognathus hankinsoni

Mylocheilus caurinus

Notropis atherinoides

Ptychocheilus oregonensis

Rhinichthys cataractae

Rhinichthys falcatus

Rhinichthys osculus

Richardsonius balteatus

Tinca tinca*

Catostomus catostomus

Catostomus colrombianus

Catostomus commersoni

Catostomus macrocheilus

Catostomus platyrhynchus

Ictalurus melas*
Ictalumus nebulosus*

Lota Zota

Gasterosteus aculeatus

Prongitius pungitius

Percopsis omiscomaycus

Lepomis gibbosus*

Micropterus dolomieui*

Micropterus salmoides*

Pomoxis nigromaculatus*

Perca flavescens*

Cottus aleuticus

Cottus asper

Cottus bairdi

Cottus cognatus

Cottus rhotheus

Cottus confusus

\section{GULF OF MEXICO WATERSHED BASIN}

27 species

Prosopizon williamsoni

Salmo clarki

salmo gairaneri

Salmo trutta

Esox Zucius

Corassius ouratus

Chrosomus eos

Chrosomus neogaeus

Conesius plrombeus
Cyprinus carpio

Hybognathus hankinsoni Hybognathus nuchalis

Pimephales promelas

Platygobio gracilis

Rhinichthys cataractae

Semotilus margarita

Catostomus catostomus

Catostomus commersoni 


\section{GULF OF MEXICO WATERSHED BASIN (cont.)}

Catostomus platyrhynchus

Moxostoma macrolepidotion

Noturus flavus

Lota Zota

Culaea inconstans
Etheostoma exile

Perca flavescens

Stizostedion canadense

Cottus bairdi

Two recent publications by Willock (1968; in press) have greatly increased knowledge of the species that occur in those limited drainages in Saskatchewan and Alberta, which are connected with the Missouri River. 


\section{LITERATURE CITED}

Bailey, R.M. 1951. A check-list of the fishes of Iowa, with keys for identification. In Iowa Fish and Fishing, by J.R. Harlan and E.B. Speaker, Iowa Cons. Comm., p. 185-237.

Bailey, R.M. and C.E. Bond. 1963. Four new species of freshwater sculpins, genus Cottus, from western North America. Occ. Pap. Mus. Zool., Univ. Michigan, No. 634. 27 p.

Carl, G.C., W.A. Clemens and C.C. Lindsey. 1959. The fresh-water fishes of British Columbia. British Columbia Prov. Mus., Handbook No. 5. 192 p.

Cole, C.F. 1967. A study of the eastern Johnny darter, Etheostoma olmstedi Storer (Teleostei, Percidae). Chesapeake Sci. 8(1): 28-51.

Cross, F.B. 1967. Handbook of fishes of Kansas. Univ. Kansas, Mus. Nat. Hist., Misc. Pub1. 45. 357 p.

Crossman, E.J. 1966. A taxonomic study of Esox americanus and its subspecies in eastern North America. Copeia 1966(1): 1-20.

Crossman, E.J. and R.G. Ferguson. 1963. The first record from Canada of Minytrema melanops. Copeia 1963(1): 186-187.

Eschmeyer, P.H. and R.M. Bailey. 1955. The pigmy whitefish, Coregonus coulteri in Lake Superior. Trans. Am. Fish. Soc. 84(1954): 161199.

Fortin, P. 1865. Continuation of the list of fishes found in the Gulf of and River St. Lawrence. In Annual report of Pierre Fortin, Esq., etc. Printed by order of the Legislative Assembly, p. 6169.

Gilbert, C.R. 1964. The American cyprinid fishes of the subgenus Luxilus (genus Notropis). Bull. Florida State Mus., Biol. Ser. $8(2): 194 \mathrm{p}$.

Halkett, A. 1913. Check list of the fishes of the Dominion of Canada and Newfoundland. King's Printer, Ottawa. 138 p.

Henderson, N.E. and R.E. Peter. 1969. Distribution of fishes of southern Alberta. J. Fish. Res. Bd. Canada 26(2): 325-338. 
Holt, R.D. 1960. Comparative morphometry of the mountain whitefish, Prosopizon williamsoni. Copeia 1960(3): 192-200.

Hubbs, C.L. and W.R. Crowe. 1956. Preliminary analysis of the American cyprinid fishes, seven new, referred to the genus Hybopsis, subgenus Emimystax. Occ. Pap. Mus. Zool., Univ. Michigan, No. 578. 8 p.

Legendre, V. 1954. Key to game and commercial fishes of the province of Quebec. The freshwater fishes. Game and Fish. Dept., Quebec, Vol. 1. 180 p.

Leim, A.H. and W.B. Scott. 1966. Fishes of the Atlantic coast of Canada. Bull. Fish. Res. Bd. Canada 155. 485 p.

Lindsey, C.C. 1962. Distinctions between the broad whitefish, Coregonus nasus, and other North American whitefishes. J. Fish. Res. Bd. Canada 19(4): 687-714.

1963. Status of the whitefish species Coregonus nelsonii Bean, and designation of a new type. Copeia 1963(1): 173-174.

MacKay, H.H. 1963. Fishes of Ontario. Ontario Dept. of Lands and Forests. $300 \mathrm{p}$.

Magnin, E. 1963. Notes sur la répartition, la biologie et particulièrement la croissance de 1'Acipenser brevirostris LeSueur 1817. Le Nat. Canadien 90(3): 87-96.

1964. Validité d'une distinction spécifique entre les deux acipenséridés: Acipenser sturio L. d'Europe et Acipenser oxyrhynchus d'Amérique du Nord. Le Nat. Canadien 91(1): 5-20.

Magnin E. and G. Beaulieu. 1963. Étude morphométrique comparée de l'Acipenser oxyrhynchus Mitchill du Saint-Laurent et de l'Acipenser sturio Linné de la Gironde. Contrib. Ministère de la Chasse et des Pêcheries No. 92.38 p.

McAllister, D.E. 1959a. Records of marine fishes from freshwater in British Columbia. Canadian Field-Nat. 73(1): 13-14.

1959b. The origin and status of the deepwater sculpin, Myoxocephalus thompsonii, a nearctic glacial relict. Bull. Nat. Mus. Canada 172: 44-65.

1960. Le Gasterosteus wheat Zandi, nouvelle espèce de poisson pour la province de Québec. Le Nat. Canadien 87(5): 117-118.

1963. A revision of the smelt family, Osmeridae. Bull. Nat. Mus. Canada 191. 53 p. 
McAllister, D.E. and C.C. Lindsey. 1961. Systematics of the freshwater sculpins (Cottus) of British Columbia. Bull. Nat. Mus. Canada 172, Contrib. Zool. 1959: 66-89.

McKenzie, R.A. 1959. Marine and freshwater fishes of the Miramichi River and Estuary, New Brunswick. J. Fish. Res. Bd. Canada $16(6)$ : $807-833$.

McPhail, J.D. 1961. A systematic study of the Salvelinus alpinus complex in North America. J. Fish. Res. Bd. Canada 18(5): 793816 .

1966. The Coregonus autromalis complex in Alaska and northwestern Canada. J. Fish. Res. Bd. Canada 23(1): 141-148.

Norden, C.R. 1961. Comparative osteology of representative salmonid fishes, with particular reference to the grayling (Thymallus arcticus) and its phylogeny. J. Fish. Res. Bd. Canada 18(5): 679-791.

Paetz, M.J. 1967. The Angler's Domain, p. 247-255. In Alberta, A Natural History, W.G. Hardy (Ed.). Mis Mat Corp. Ltd., Edmonton. $343 \mathrm{p}$.

Paetz, M.J. and J.S. Nelson. 1968. Keys to the fishes of Alberta. 25 p. (mimeo).

Qadri, S.U. 1959. Some morphological differences between the subspecies of cutthroat trout, Salmo clarkii clarkii and Salmo clarkii lewisi, in British Columbia. J. Fish. Res. Bd. Canada 16(6): 903-922.

Ryder, R.A., W.B. Scott and E.J. Crossman. 1964. Fishes of northern Ontario, north of the Albany River. Roy. Ontario Mus., Life Sciences Contrib. No. 60. 30 p.

Sale, P.F. 1967. A re-examination of the taxonomic position of the aurora trout. Canadian J. Zool. 45: 215-225.

Scott, W.B. 1958. A checklist of the freshwater fishes of Canada and Alaska. Roy. Ontario Mus., Div. Zool. Palaeo. 30 p.

1967. Freshwater fishes of eastern Canada. Toronto, Univ. Toronto Press (2nd ed. revised). $137 \mathrm{p}$.

Scott, W.B. and E.J. Crossman. 1959. The freshwater fishes of New Brunswick: a checklist with distributional notes. Roy. Ontario Mus., Div. Zool. Palaeo., Contrib. No. 51.37 p. 
1964. Fishes occurring in the fresh waters of insular Newfoundland. Canada, Department of Fisheries. $\$ 24$ p.

1967. Provisional checklist of Canadian freshwater fishes. Roy. Ontario Mus. Info. Leaflet. $39 \mathrm{p}$.

Smith, G.R. 1966. Distribution and evolution of the North American catostomid fishes of the subgenus Pantosteus, genus Catostomus. Univ. Michigan, Mus. of Zoology, Misc. Pub1. No. 129. 132 p.

Suttkus, R.D. 1958. Status of the nominal cyprinid species Moniana deliciosa Girard and CyprinelZa texana Girard. Copeia 1958(4): 307-318.

Svetovidov, A.N. and E.A. Dorofeeva. 1963. Systematics, origin and history of the Eurasian and North American perches and pikeperches (genera Perca, Lucioperca, and Stizostedion). Voprosy Ikhtiol., 3(4): 625-651.

Vladykov, V.D. and W.I. Follett. 1958. Redescription of Lampetra ayresii (Gunther) of western North America, a species of lamprey (Petromyzontidae) distinct from Lampetra fluviatilis (Linnaeus) of Europe. J. Fish. Res. Bd. Canada 15(1): 47-77.

1965. Lampetra richardsoni, a new nonparasitic species of lamprey (Petromyzontidae) from western North America. J. Fish. Res. Bd. Canada 22(1): 139-158.

Walters, V. 1955. Fishes of western Arctic America and eastern Arctic Siberia. Bull. Am. Mus. Nat. Hist. 106(5): 225-368.

Wilimovsky, N.J. 1954. List of the fishes of Alaska. Stanford Ichthyol. Bul1. 4(5): 279-294.

Willock, T.A. 1968. New Alberta records of the silvery and brassy minnows, stonecat, and sauger, with a preliminary list of the fishes of the Milk River in Alberta. Canadian Field-Nat. 82(1): 18-23.

(in press). Annotated checklist of fishes of the Missouri drainage in Canada. J. Fish. Res. Bd. Canada.

Whitley, G.P. 1950. New fish names. Proc. Roy. Zool. Soc. New South Wales $(1948-49)$. p. 44.

Wynne-Edwards, V.C. 1952. Freshwater vertebrates of the arctic and subarctic. Bull. Fish. Res. Bd. Canada 94. 28 p. 



\section{INDEX}

Underlined page numbers indicate location in the keys. Page numbers not underlined refer to position in the checklist.

Acipenser brevirostrum, 8, 34

fulvescens, 8,34

medirostris, $8, \frac{34}{34}$

oxyrhynchus, $8, \overline{33}$

sturio, 8

transmontanus, 8, 33

Acipenseridae, 8, 26

key to, 33

Acipenseriformes, 8

Acrocheilus alutuceum, 14, 49

alutaceus, 14

Agnatha, 7

Alaska blackfish, 14

Aleutian sculpin, 24

alewife, 9,35

Alosa aestivalis, 9, 35

pseudoharengus, 9,35

sapidissima, 9, 35

Ambloplites mupestris, 22, 64

American brook lamprey, $7, \underline{\overline{32}}$

American ee1, 20

American sand lance, 75

American shad, 9, 35

American smelt, 13

Amia calva, 9

Amildae, 9, 26

Amilformes, 9

Armocrypta pellucida, 23, 69

Ammodytes americanus, 75

Ammodytidae, 75

Anacanthini, 21

Anguizza rostrata, 20

Angulllidae, 20, 26

Anguilliformes, 20

Apeltes quadracus, $21, \frac{63}{24}$

Aplodinotus grunniens, 24

Apodes, 20

Arctic char, 10,38

Arctic cisco, 11

Arctic grayling, 13, 39

Arct1c lamprey, 7, 31

Arctic smelt, 13

Atherinidae, 21, 30

Atheriniformes, 21 
Atlantic salmon, $10, \underline{37}, 75$

Atlantic sturgeon, $8, \underline{33}$

Atlantic tomcod, 21

banded killifish, 20, 61

basses, 22, 30

Bering cisco, 12

bigmouth buffalo, 19, 55

black bullhead, 19, 60

black crapple, 23,66

black redhorse, 19,58

blackchin shiner, 16, 53

blackfin cisco, 12

blackf1sh, 28,43

blacknose dace, 17,46

blacknose shiner, 16, 53

blackside darter, 24, 70

blackspot stickleback, $\overline{21}, 63$

bloater, 12

blue pike, 24,68

blueback herring, 9, 35

blueg111, 22, 66

bluntnose minnow, 17,50

Bothidae, 75

bowfin, 9

bowfins, 26

brassy minnow, 15, 54

bridgelip sucker, $1 \overline{8}, 56$

bridle shiner, 16, 53

brindled madtom, 20, 61

broad whitefish, $12, \overline{40}$

brook silverside, 21

brook stickleback, 21, 63

brook trout, 11,38

brown bullhead, 20,60

brown trout, 10, 37

burbot, 21, 62

Carassius auratus, 15, 45

carp, 15, 45

Carpiodes cypminus, 18,55

catfishes, 19, 27

Catostomidae, $1 \overline{8}, 29$

key to, 54

Catostomus catostomus, 18, 56

columbianus, 18,56

commersoni, $18,5 \overline{7}$

macrocheilus, 18,57

platyrhynchus, $18, \overline{57}$ 
central Johnny darter, 23

central mudminnow, 14, 43

Centrarchidae, 22, 30

key to, 64

chain pickerel, 14, 44

channel catfish, 20, 59

channel darter, 69

chars, 36

chestnut 1amprey, 7,32

chinook salmon, $10, \underline{39}$

chiselmouth, 14,49

Chondrostei, 8

Chrosomus eos, 15,48

neogaeus, $15, \overline{48}$

chum salmon, 10,39

Cichlidae, 75

cichlids, 75

Cichlosoma nigrofasciatum, 75

cisco, 11

ciscoes, 27

Clinocottus acuticeps, 75

Clinostomus elongatus, 15, 49

Clupea harengus pallasi, 75

Clupeidae, 9, 29, 75

key to, 35

Clupeiformes, $\frac{}{9}$

coastal cutthroat trout, 10

coastrange sculpin, $24, \underline{74}$

cods, 21, 30

coho salmon, 10, 39

common shiner, 16

copper redhorse, 19, 58

Coregonidae, 9

Coregoninae, 11, 27, 36, 39

Coregonus alpenae, 11

artedii, 11

autumnalis, 11,12

clupeaformis, 11,41

hoyi, 12

johannae, 12

kiyi, 12

Zaurettae, 11, 12

nasus, 12,40

nelsoni, 11

nigmipinnis, 12

nipigon, 12

pidschian, 11

reighardi, 12

sardine Zla, 12

sp., 12, 41 
zenithicus, 12

Cottidae, 24, 29, 75

key to, 72

Cottus aleuticus, 24, 74

asper, 24, 74

bairdi, 24,73

cognatus, $24, \frac{73}{73}$

confusus, $25, \underline{73}$

hubbsi, 24

philonips, 24

rhotheus, 25,73

ricei, 25, 72

sp., 25

Conesius, 15

plumbeus, 15, 47

creek chub, 18,50

creek shiner, $\underline{51}$

Culaea inconstans, 21,63

cutlips minnow, 15,45

cutthroat trout, $10, \frac{37}{37}$

Cyclopteridae, 75

Cyclopterus Zumpus, 75

Cymatogaster aggregata, 75

Cyprinidae, 14, 29

key to, 45

Cypriniformes, 14

Cyprinodontidae, 20, 28, 75

key to, 61

Cyprinodontiformes, 20

Cyprinus carpio, 15, 45

Dallia pectoralis, $14, \underline{43}$

Dallifdae, 14

deepwater cisco, 12

deepwater sculpin, 25, 72

dogfish sharks, 75

Dolly Varden, 11, 38

Dorosoma cepedianum, 9, 35

drums, 24, 30

Embiotocidae, 75

emerald shiner, 16, 52

Entosphenus japonicus, 7

lamottei, 7

tridentatus, 7

Erimystax, 15

dissimilis, 15

Erimyzon sucetta, 18, 55 
Esocidae, 14,28

key to, 43

Esox anericanus, 14

conericanus conericanus, 14,44

comericanus vermiculatus, 14,44

Zucius, 14,44

masquinongy, 14, 44

niger, 14,44

Etheostoma blennioides, 23, 71

(Boleosoma) nigrum, 23

caeruleum, 23, 71

exile, 23, 71

flabezzare, 23,71

maculatum, 70

microperca, 23,71

nigmom, 23, 70

nigrum eurepis, 23

nigmom nigmom, 23

nigmum olmstedi, 23

olmstedi, 23

Eucalia inconstans, 21

eulachon, 13, 42

European brook lamprey, 7

Exoglossum maxillingua, 15, 45

fallfish, $18, \underline{49}$

Families, key to, 26

fantail darter, 23, 71

fathead minnow, $17, \overline{50}$

finescale dace, $15, \overline{48}$

flathead chub, $17,4 \overline{6}$

fourhorn sculpin, $7 \overline{5}$

fourspine stickleback, 21, 63

freshwater drum, 24

freshwater eels, 20, 26

Fundulus diaphanus, 20,61 heteroclitus, $20,6 \overline{1}$

Gadidae, 21,30

key to, $\overline{62}$

Gadiformes, 21

Gambusia affinis, 20

gar pikes, 28

gars, 8

Gasterosteidae, 21,30

key to, 62

Gasterosteiformes, 21 


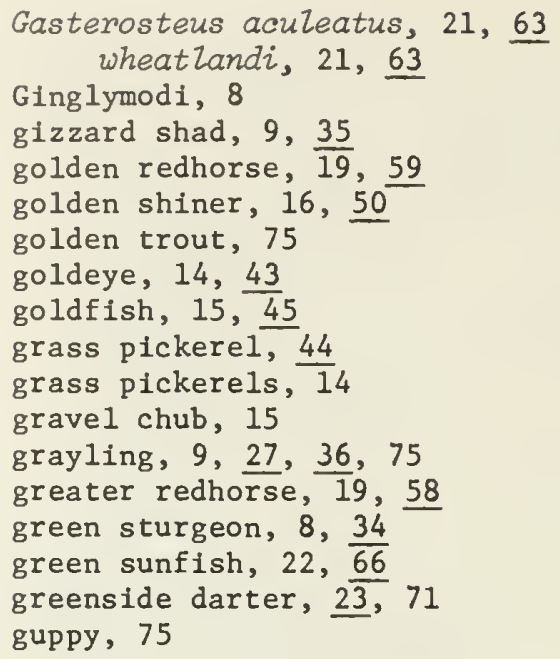

Halecomorphi, 9

herrings, 9, 29, 75

Hiodon alosoides, 14, 43 tergisus, 14, 43

Hiodontidae, 14, 29 key to, 43

hornyhead chub, 16, 47

humpback whitefish, $\overline{11}$

Hybognathus hankinsoni, 15, 54 nuchalis, $15, \frac{54}{16}$

Hybopsis biguttata,
micropogon, 16 storeriana, 15,48 $x$-punctata, $15, \overline{48}$

Hypentelium nigricans, 19, 56 Hyperoartia, 7

Hypomesus olidus, 13, 42

Ichthyomyzon castaneus, 7, 32 fossor, 7,33 unicuspis, 7,33

Ictaluridae, 19, 27 key to, 59

Ictalums melas, 19,60 natalis, 19,60 nebulosus, 20,60 punctatus, $20, \overline{59}$

Ictiobus bubalus, 19 cyprinelzus, 19, 55 
inconnu, 13, 41

Iowa darter, $\overline{23}, 71$

Isospondyli, 9

Johnny darter, 70

Kamloops trout, 10

killifishes, 20, 28, 75

kiyi, 12

kokanee, 10, 39

Labidesthes sicculus, 21

lake Atlantic salmon, 10

lake chub, 15, 47

lake chubsucker, 18,55

lake herring, 11

lake sturgeon, 8,34

lake trout, 11,38

lake whitefish, $11, \frac{41}{32}$

Lampetra ayresi, $7, \underline{32}$

fluviatilis, 7

japonica, 7,31

Zamotte $i, 7, \underline{32}$

planemi, 7

michardsoni, 7, 32

tridentata, 7, 31

lampreys, 7, 26

key to, $\frac{26}{31}$

largemouth bass, 23, 65

largescale sucker, 18, 57

lauretta herring, 11

least cisco, 12

least darter, 23, 71

Lebistes reticulatus, 75

lefteye flounders, 75

leopard dace, 17,47

Lepisosteidae, $8, \overline{28}$

key to, 34

Lepisosteiformes, 8

Lepisosteus oculatus, 8

osseus, 8, 35

productus, $\overline{8}, 35$

Lepomis aumitus, 22, 66

cyanellus, $22, \underline{6 \overline{6}}$

gibbosus, $22, \underline{65}$ 
macrochirus, 22,66

megalotis, 23,66

Leptocottus armatus, 75

Leucichthys, 9, 41

Liopsetta putnami, 76

logperch, 24, 69

longear sunfish, 23,66

longf in smelt, $13, \underline{42}$

longjaw cisco, 11

longnose dace, $17, \underline{46}$

longnose gar, 8,35

longnose sucker, $\overline{18}, 56$

Lota Zota, 21, 62

lumpfish, 75

lumpfishes, 75

Margariscus margarita nachtriebei, 18

Marsipobranchil, 7

Meganostomatobus cyprinella, 19

Microcyprini, 20

Microgadus tomcod, 21,62

Micropterus dolomieui, $\overline{23}, 65$ salmoides, 23,65

mimic shiner, 17,54

minnows, 14

Minytrema melanops, 19,55

Moliienesia Latipinna, 75

mooneye, 14,43

mooneyes, $14, \frac{29}{20}$

mosquitofish, 20

mottled sculpin, 24, 73

mountain sucker, $18, \frac{57}{37}$

mountain whitefish, 13,40

Moxostoma anisumu, 19,

aureolum, 19

carinatum, 19,58

duquesnei, 19,58

erythrumu, 19, 59

hubbsi, 19,58

macrolepidotum, 19,59

valenciennesi, 19,58

mudminnows, 14,28

mummichog, 20, 61

muskellunge, 14,44

Mylocheilus caurinum, 15, 47

caurinus, 15

Myoxocephalus quadricomis, 25, 72, 75

thompsoni, 25 


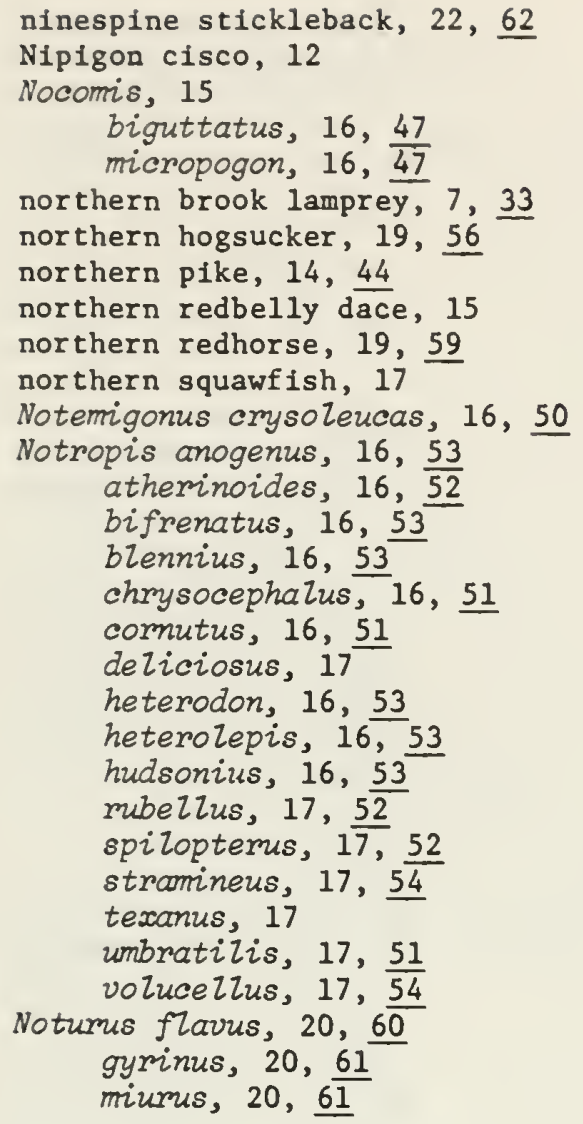

Oncorhynchus gorbuscha, 9, 39

keta, 10, 39

kisutch, 10, 39

nerka, 10, 39

spp., 36

tshowytscha, 10, 39

opsopoeodus emiliae, 17, 51

Osmeridae, 13, 27

key to, 42

Osmems dentex, 13

epertanus, 13,42

eperlanus dentex, 13

epertanus mordax, 13

mordax, 13

Ostariophysi, 14

Osteichthyes, 8

ouananiche, 10 
Pacific herring, 75

Pacific lamprey, 7, 31

Pacific salmons, 36

Pacific staghorn sculpin, 75

Pantosteus jordani, 18

Zahontan, 18

platyrhynchus, 18

peamouth, 15

peamouth chub, 47

pear 1 dace, 18,50

Perca flavescens, 23, 67

fluviatilis, 23

perches, 23, 30

Percidae, $23, \frac{30}{67}$

key to, $6 \overline{7}$

Perciformes, $\overline{22}$

Percina caprodes, 24, 09

copelandi, 24, 69

maculata, 24

shumardi, 24, 70

Percomorphi, 22

Percopsidae, 22, 27

Percopsiformes, 22

Percopsis omiscomaycus, 22

Petromyzon marinus, 8, 31

Petromyzontidae, 7,26

key to, 31

Petromyzont iformes, 7

Pfrille neogaea, 15

pikes, 14, 28

Pimephales notatus, 17, 50 promelas, 17,50

pink salmon, 9, 39

Pisces, 8

Platichthys stellatus, 76

Platygobio, 15

gracizis, 17,46

Pleuronectidae, 76

Pomoxis annularis, 23, 66

nigromaculatus, 23,66

pond smelt, 13, 42

prickly sculpin, 24,74

Prosopium coulteri, $\overline{12}, 40$

cylindraceum, $12,4 \overline{0}$

oregonium, 13

spp., 40

wizliamsoni, 13,40

Protospondyli, 8

Pseudopleuronectes americanus, 76

Ptychocheilus oregonense, 17, 49

oregonensis, 17 
pugnose minnow, 17, 51

pugnose shiner, $16, \underline{53}$

pumpkinseed, 22, 65

Pungitius pungitius, 22, 62

pygmy whitefish, 12,40

Quebec red trout, 10

quillback, 18, 55

rainbow darter, 23, 71

rainbow smelt, $13,4 \frac{42}{37}$

rainbow trout, $10, \overline{37}$

redbelly dace, 48

redbreast sunfish, 22, 66

redfin pickerel, 44

redfin pickerels, 14

redfin shiner, 17,51

redside dace, 15,49

redside shiner, 18,49

Rhinichthys atratulus, 17, 46

cataractae, 17,46

falcatus, 17,47

osculus, $17,4 \overline{9}$

Richardsonius baiteatus, 18,49

righteye flounders, 76

river chub, 16,47

river darter, $24, \frac{70}{32}$

river lamprey, 7,32

river redhorse, $19, \underline{58}$

river shiner, 16,53

Roccus americanus, 22,63

chrysops, 22,64

saxatilis, 22,64

rock bass, 22,64

rosyface shiner, 17,52

round whitefish, $12, \underline{40}$

round whitefishes, 40

Sacramento smelt, 13

sailfin molly, 75

Salmo aguabonita, 75

clarki, 10, 37

clarki clarki, 10

clarki Zewisi, 10

gairdneri, 10, 37

salar, $10, \underline{37}, \overline{75}$

trutta, 10, 37 
Salmonidae, 9, 27, 75

key to, 36

Salmoninae, $9, \frac{27}{36}, \frac{36}{75}$

salmons, $9, \underline{27}, \underline{36}, \frac{75}{75}$

Salmopercae, 22

Salveiinus alpinus, 10, 11, 38

aureolus, 10

fontinalis, 11,38

malma, 10, 11, 38

marstoni, 10

namaycush, 11, 38

oquassa, 10

timagamiensis, 11

sand darter, 23, 69

sand lances, 75

sand shiner, 17,54

sauger, 24,68

Schilbeodes gyrinus, 20

miums, 20

Sciaenidae, 24,30

Scophthalmus aquosus, 75

sculpins, 24, 29, 75

sea lamprey, 8,31

Semionotiformes, $\frac{7}{8}$

Semotilus atromaculatus, 18, 50 corporalis, 18,49

margarita, 18,50

Serranidae, 22, 30

key to, 63

sharpnose sculpin, 75

shiner perch, 75

shorthead sculpin, 25, 73

shortjaw cisco, 12

shortnose cisco, 12

shortnose sturgeon, 8,34

silver chub, 15,48

silver lamprey, 7,33

silver redhorse, 19,58

silversides, 21,30

silvery minnow, $1 \overline{5}, 54$

slimy sculpin, 24,73

smallmouth bass, 23, 65

smallmouth buffalo, 19

smelts, 13, 27

smooth flounder, 76

snailfishes, 75

sockeye salmon, 10,39

speckled dace, $17,4 \overline{9}$

spiny dogfish, 75 
Spirinchus dizatus, 13

thaleichthys, 13,42

splake, 11

spoonhead sculpin, $25, \underline{72}$

spotfin shiner, 17,52

spottail shiner, 16,53

spotted chub, 48

spotted gar, 8,35

spotted sucker, 19,55

Squalidae, 75

Squalus acanthias, 75

squawf ish, 49

starry flounder, 76

steelhead trout, 10

Stenodus leucichthys, 13, 41

sticklebacks, $21, \underline{30}$

Stizostedion canadense, 24,68

vitreum, 24,68

vitreum glaucum, 24, 68

vitreum vitreum, 68

stonecat, 20,60

striped bass, 22,64

striped shiner, 16

sturgeons, 8,26

suckers, 18,29

sunfishes, 22,30

surfperches, 75

swordtail, 75

tadpole madtom, 20, 61

tench, 18, 46

Thaleichthys pacificus, 13, 42

Thoracostei, 21

threespine stickleback, 21, 63

Thymallidae, 9

Thymallinae, 13, 27, 36

Thymallus arcticus, 13, 39

Tinca tinca, 18, 46

tomcod, 62

torrent sculpin, 25, 73

Triglopsis thompsoni, $\frac{73}{25}$

trout-perch, 22, 27

trout-perches, 22

trouts, 9, 27, 36,75

tullibee, 11

Umbra limi, 14, 43

Umbridae, 14,28

key to, 43 
walleye, $24, \underline{68}$

wendigo, 11

western brook lamprey, 7, 32

white bass, 22,64

white crappie, $2 \overline{3}, 66$

white perch, 22,63

white sturgeon, 8,33

white sucker, $18, \underline{57}$

whitefish, 41

whitefishes, $9,27,36,39,75$

windowpane, 75

winter flounder, 76

Xiphophoms hellem, 75

yellow bu11head, 19, 60

yellow perch, 23,67

yellow walleye, 24

yellowbelly sunfish, 22

Yellowstone cutthroat trout, 10

Yukon whitefish, 11

zebra cichlid, 75 


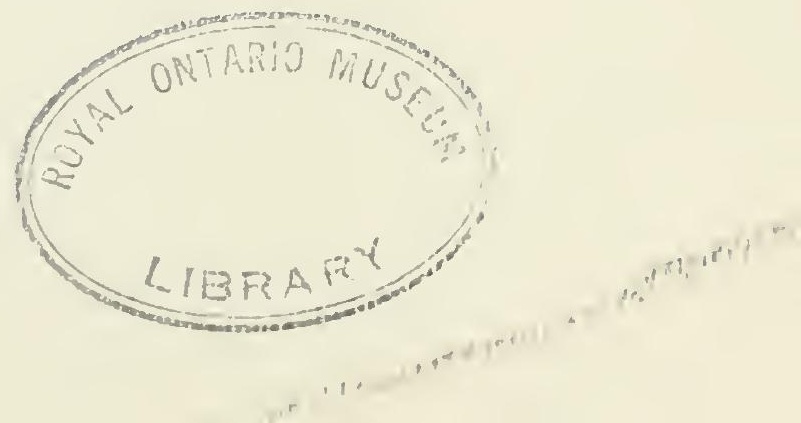


. 